Article

\title{
Bimetallic Pt-Co Catalysts for the Liquid-Phase WGS
}

\author{
Alberto José Reynoso ${ }^{1}{ }^{(}$, Jose Luis Ayastuy ${ }^{1, *}$, Unai Iriarte-Velasco ${ }^{2}$ \\ and Miguel Ángel Gutiérrez-Ortiz ${ }^{1}$ \\ 1 Department of Chemical Engineering, Faculty of Science and Technology, University of the Basque Country \\ UPV/EHU, Sarriena S/N, 48940 Leioa, Spain; albertojose.reynoso@ehu.eus (A.J.R.); \\ miguelangel.gutierrez@ehu.eus (M.Á.G.-O.) \\ 2 Department of Chemical Engineering, Faculty of Pharmacy, University of the Basque Country UPV/EHU, \\ Paseo de la Universidad, 7, 01006 Vitoria, Spain; unai.iriarte@ehu.eus \\ * Correspondence: joseluis.ayastuy@ehu.eus; Tel.: +34-94-601-2619
}

Received: 30 June 2020; Accepted: 22 July 2020; Published: 24 July 2020

\begin{abstract}
Bimetallic Pt-Co catalysts derived from cobalt aluminate spinel were investigated in the liquid-phase water-gas shift (WGS) reaction and CO hydrogenation. Liquid-phase WGS is a key reaction in the aqueous-phase reforming (APR) of polyols; thus, WGS activity is essential to formulate good APR catalysts. In this work, catalysts with different $\mathrm{Pt} / \mathrm{Co}$ molar ratios were synthesized together with a reference Pt/alumina. All the synthesized catalysts were characterized by various techniques in order to gain knowledge on their structural and surface characteristics. WGS activity was tested with a feedstream of $\mathrm{CO} / \mathrm{H}_{2} \mathrm{O}=1 / 15$ (space-time of $76.8 \mathrm{~kg}_{\text {cat }} \cdot \mathrm{s} / \mathrm{mol}_{\mathrm{CO}}$ ), isothermal operation at $260{ }^{\circ} \mathrm{C}$ and 50 bar, for 10 TOS. Bimetallic Pt-Co catalysts showed improved activity in liquid-phase WGS in comparison to bare Co or Pt catalysts, which was ascribed to the synergistic effect. Despite being subjected to an increased hydrogen concentration in the feedstream $\left(\mathrm{H}_{2} / \mathrm{CO}\right.$ between 0 and 12/3), these catalysts maintained a preferential selectivity towards WGS activity. In addition, the effect of temperature $\left(220-260{ }^{\circ} \mathrm{C}\right)$ and pressure $(25-50$ bar) was investigated over a catalyst with $0.3 \mathrm{Pt} / \mathrm{CoAl}$. $\mathrm{CO}$ conversion and $\mathrm{CO}_{2}$ yield were more sensitive to temperature, while a higher pressure favored methane production. The measured activation energy in the $220-260{ }^{\circ} \mathrm{C}$ temperature range was $51.5 \mathrm{~kJ} / \mathrm{mol}$.
\end{abstract}

Keywords: hydrogen; WGS; hydrogenation; cobalt; platinum

\section{Introduction}

The water-gas shift (WGS) reaction, first observed by Felice Fontana in 1780 [1], is related to the production of hydrogen and carbon dioxide from a mixture of carbon monoxide and steam. WGS is a key element in mature technologies devoted to hydrogen production by the steam reforming of natural gas in industrial applications such as ammonia synthesis or synthesis gas plants. In recent decades, due to the growing concerns about environmental issues and the challenge of implementing the hydrogen economy, research on new catalysts for the WGS reaction has been notably boosted [2]. This renewed interest in WGS has been motivated by the search for renewable feedstocks as alternatives to fossil fuels, which are to blame for environmental problems such as global warming. Gas-phase WGS is a well-studied, reversible and exothermic reaction that can be catalyzed by a wide range of metals and metal oxides, such as $\mathrm{Fe}, \mathrm{Cu}, \mathrm{Cr}, \mathrm{Au}, \mathrm{Pt}$ and $\mathrm{Co}$ [3]. To overcome the equilibrium limitations, industrially, WGS is carried out in two consecutive stages, with intermediate cooling. Otherwise, a sorption-enhanced WGS reaction can be used to intensify the process by the in-situ removal of $\mathrm{CO}_{2}$ to shift the equilibrium towards hydrogen production [4]. Homogeneous WGS is carried out using different transition metal complexes $(\mathrm{Rh}, \mathrm{Ru})$, even under mild conditions, which are usually doped with organic bases to increase the turnover rate [5,6]. Supported ionic liquids (SILP), prepared via the 
immobilization of ionic liquids on the solid material, have also been used for WGS [7]. In addition, hydrogen can be produced through the use of organisms that use the biological WGS reaction as a means of obtaining energy to maintain their metabolic processes and grow [8].

The WGS reaction plays an essential role in the aqueous-phase reforming (APR) reaction mechanism of oxygenated hydrocarbons (polyols). The APR process is carried out in the liquid phase at mild operation conditions (200-260 ${ }^{\circ} \mathrm{C}$ and sufficient pressure to assure liquid phase) [9]. For hydrogen production, APR is more advantageous than vapor-phase reforming because it eliminates the need to vaporize water with the consequent energy saving, extends the feedstock choices to non-volatile oxygenates and minimizes the undesirable parallel reactions, as is the case when carried out at lower temperatures.

The $\mathrm{C}-\mathrm{C}$ cleavage of the polyol gives $\mathrm{CO}$ as a primary product of the aforementioned APR reaction (Equation (1)), which should be removed from the catalyst surface in order to keep it available for further polyol conversion. The $\mathrm{CO}$ is then removed from the reaction mixture by the WGS reaction (Equation (2)), which generates additional $\mathrm{H}_{2}$ [10]. In this way, the WGS reaction becomes a key step in the APR to obtain hydrogen from polyols, with minor production of alkanes (mainly methane) and high selectivity to hydrogen. For the APR of polyols with chemical formulae $\mathrm{C}_{n} \mathrm{H}_{2 n+2} \mathrm{O}_{n}$, the sugar alcohol reforming (Equation (1)) and the WGS (Equation (2)) reactions are coupled, to give the global APR reaction (Equation (3)):

$$
\begin{gathered}
\mathrm{C}_{\mathrm{n}} \mathrm{H}_{2 \mathrm{n}+2} \mathrm{O}_{\mathrm{n}} \rightarrow \mathrm{nCO}+(\mathrm{n}+1) \mathrm{H}_{2} \\
\mathrm{nCO}+\mathrm{nH}_{2} \mathrm{O} \leftrightarrow \mathrm{nCO}_{2}+\mathrm{nH}_{2} \\
\mathrm{C}_{\mathrm{n}} \mathrm{H}_{2 \mathrm{n}+2} \mathrm{O}_{\mathrm{n}}+\mathrm{nH}_{2} \mathrm{O} \rightarrow \mathrm{nCO}_{2}+(2 \mathrm{n}+1) \mathrm{H}_{2}
\end{gathered}
$$

Virtually all the studies carried out to correlate WGS activity with the APR process are performed considering that the WGS reaction occurs under the same thermodynamic and kinetic conditions as those studied in the gas phase [11-13]. Nonetheless, Ripken et al. modeled the WGS reaction in the liquid phase and concluded that the phase state of water as a reactant influenced the mechanism of the WGS reaction. In addition, they concluded that the reaction was slightly endothermic in the liquid phase $(\Delta \mathrm{H}=+2.88 \mathrm{~kJ} / \mathrm{mol})$, in contrast to the exothermic nature $(\Delta \mathrm{H}=-41.1 \mathrm{~kJ} / \mathrm{mol})$ in the gas-phase reaction [14]. Even so, there are few investigations focused on the liquid-phase WGS reaction [15].

On the basis of APR conditions, alkane formation, mainly methane, by carbon hydrogenation is highly favorable [10]. Both $\mathrm{CO}$ and $\mathrm{CO}_{2}$ methanation (Equations (4) and (5)) are hydrogen-consuming reactions; therefore, these are undesirable in the APR reforming of biomass-derived compounds targeting efficient hydrogen production. In like manner, the number of works focused on the production of methane through the hydrogenation of $\mathrm{CO}$ at hydrothermal conditions is small.

The overall methanation process can be represented by the following reactions:

$$
\begin{aligned}
& \mathrm{CO}+3 \mathrm{H}_{2} \leftrightarrow \mathrm{CH}_{4}+\mathrm{H}_{2} \mathrm{O} \\
& \mathrm{CO}_{2}+4 \mathrm{H}_{2} \leftrightarrow \mathrm{CH}_{4}+2 \mathrm{H}_{2} \mathrm{O}
\end{aligned}
$$

Recently, significant progress has been achieved with CoAl-based catalysts for glycerol APR [16]. Noble metals were shown to be very active in the APR of oxygenated organic compounds $[17,18]$ and the WGS reaction [19], and, linked to the promotional effect of bimetallic catalysts, this makes the Pt-Co alloy an ideal catalyst to be studied in this type of process [20-22]. Even though cobalt has been reported to be active in methanation reactions [23], according to our current knowledge, the scope of these side reactions over cobalt-based catalysts under APR conditions has not been established yet. In the APR of polyols, methane can be formed by either hydrogenation of $\mathrm{CO}$ or by via $\mathrm{C}-\mathrm{C}$ cleavage and subsequent hydrogenation. Therefore, it would be of great interest to elucidate whether the hydrogenation of $\mathrm{CO}$ could proceed to a large extent as it would affect the APR selectivity to hydrogen. In view of all this, we studied the WGS reaction under similar operation conditions to those previously used to investigate APR on bimetallic Pt-Co catalysts derived from cobalt aluminate 
precursor [24]. With this purpose in mind, different amounts of platinum were impregnated on cobalt aluminate $(\mathrm{Co} / \mathrm{Al}=0.625$ mole ratio). The catalytic results in both processes were correlated with the intrinsic characteristics of the catalysts.

\section{Results and Discussion}

\subsection{Catalyst Characterization}

A summary of the measured physico-chemical properties of the catalysts is shown in Table 1. For all the samples, the actual platinum content and $\mathrm{Co} / \mathrm{Al}$ atomic ratio were very close to the nominal value. Pt-containing samples presented a larger specific surface area $\left(\mathrm{S}_{\mathrm{BET}}\right)$ and pore volume $\left(\mathrm{V}_{\text {pore }}\right)$ than CoAl. The addition of Pt seemed to shift the pore size $\left(\mathrm{d}_{\text {pore }}\right)$ of the $\mathrm{xPt} / \mathrm{CoAl}$ samples towards higher values. After reduction, $\mathrm{S}_{\mathrm{BET}}$ of the resultant catalysts decreased while $\mathrm{d}_{\text {pore }}$ increased, except for $0.3 \mathrm{Pt} / \mathrm{Al}$, which preserved its textural properties. Pore size distribution, calculated from the nitrogen adsorption-desorption isotherms (Figure S1, Supplementary Materials), revealed that both the calcined and reduced samples were mainly mesoporous materials.

Table 1. Physico-chemical properties of the catalysts.

\begin{tabular}{|c|c|c|c|c|c|c|c|c|}
\hline Catalyst & $\begin{array}{c}\text { Actual Pt }{ }^{\text {a }} \\
\text { (wt.\%) }\end{array}$ & Bulk Co/Al a & $\mathrm{S}_{\mathrm{BET}}{ }^{\mathrm{b}}\left(\mathrm{m}^{2} / \mathrm{g}\right)$ & $d_{\text {pore }}{ }^{b}(n m)$ & $\mathrm{V}_{\text {pore }}{ }^{\mathrm{b}}\left(\mathrm{cm}^{3} / \mathrm{g}\right)$ & $\mathrm{d}_{\text {spinel }}{ }^{\mathrm{c}}(\mathrm{nm})$ & $\begin{array}{l}\mathrm{d}_{\mathrm{Co}}{ }^{\mathrm{d}} \\
(\mathrm{nm})\end{array}$ & $a^{c}(n m)$ \\
\hline CoAl & 0 & 0.634 & $125(102)$ & $6.8(11.8)$ & $0.28(0.38)$ & 5.0 & 14.7 & $0.8042 \pm 0.0014$ \\
\hline $0.3 \mathrm{Pt} / \mathrm{CoAl}$ & 0.29 & 0.633 & $146(131)$ & $12.7(14.8)$ & $0.56(0.52)$ & 6.3 & 6.9 & $0.8052 \pm 0.0011$ \\
\hline 1Pt/CoAl & 1.09 & 0.623 & 139 (126) & $12.8(14.9)$ & $0.54(0.51)$ & 6.3 & 6.5 & $0.8063 \pm 0.0060$ \\
\hline $0.3 \mathrm{Pt} / \mathrm{Al}$ & 0.36 & n.d. & 138 (138) & $3.9(4.0)$ & $0.19(0.20)$ & n.d. & n.d. & n.d. \\
\hline
\end{tabular}

${ }^{a}$ from ICP-AES. ${ }^{b}$ from nitrogen isotherms. In parentheses are values for the reduced samples. ${ }^{c}$ lattice parameter from XRD of the calcined samples. ${ }^{\mathrm{d}}$ metallic cobalt size from XRD of the reduced samples.

The phase composition and morphology of the samples was evaluated by XRD, and the obtained diffraction patterns are shown in Figure 1. Calcined $\mathrm{CoAl}$ and $\mathrm{xPt} / \mathrm{CoAl}$ samples (Figure 1A) presented the characteristic diffraction peaks of cobalt aluminate (PDF 00-044-0160) and cobalt oxide (PDF 00-042-1467) spinels. Both species, with cubic crystal system and Fd3m space group, have almost the same diffraction angles and only could be distinguished by their different lattice parameters (smaller for $\mathrm{Co}_{3} \mathrm{O}_{4}$ ). The lattice parameter (a) of the calcined spinel phase was calculated from the Bragg equation, which holds for the $f_{c c}$ structure:

$$
a=\frac{\lambda}{2 \sin \theta} \sqrt{h^{2}+k^{2}+l^{2}}
$$

The calculated parameter for the bare CoAl sample was $8.042 \AA$, which was lower than the lattice constant of standard stoichiometric $\mathrm{CoAl}_{2} \mathrm{O}_{4}(8.104 \AA)$. This could be due to the non-stoichiometric composition of $\mathrm{CoAl}$, caused by the higher $\mathrm{Co} / \mathrm{Al}$ mole ratio $(0.634)$ compared to the corresponding stoichiometric one. After the addition of $\mathrm{Pt}$, the lattice parameter increased slightly, proportionally to platinum content, suggesting that Pt strongly interacted with the support. The average crystallite size of the spinel phase of the calcined samples was estimated by means of the Scherrer equation and indicated an increase of $26 \%$ with platinum addition. No characteristic peak of Pt species was observed, probably because of their high dispersion and low loadings. Catalyst $0.3 \mathrm{Pt} / \mathrm{Al}$ showed characteristic peaks of $\gamma$-alumina, with a clear baseline elevation, indicative of its amorphous nature.

Regarding the reduced assays (Figure 1B), cobalt-containing catalysts showed diffraction peaks ascribed to metallic Co, prevailing in the $f c c$ phase with respect to the $h c p$ phase. In addition, the aforementioned cobalt spinel phase could be still identified. However, as for the calcined samples, no peak in metallic Pt was detected. After Pt loadings, metallic cobalt crystallite size decreased by half, suggesting that $\mathrm{Pt}$ acts as a structural promoter which decreases metallic Co particle size (Table 1). 

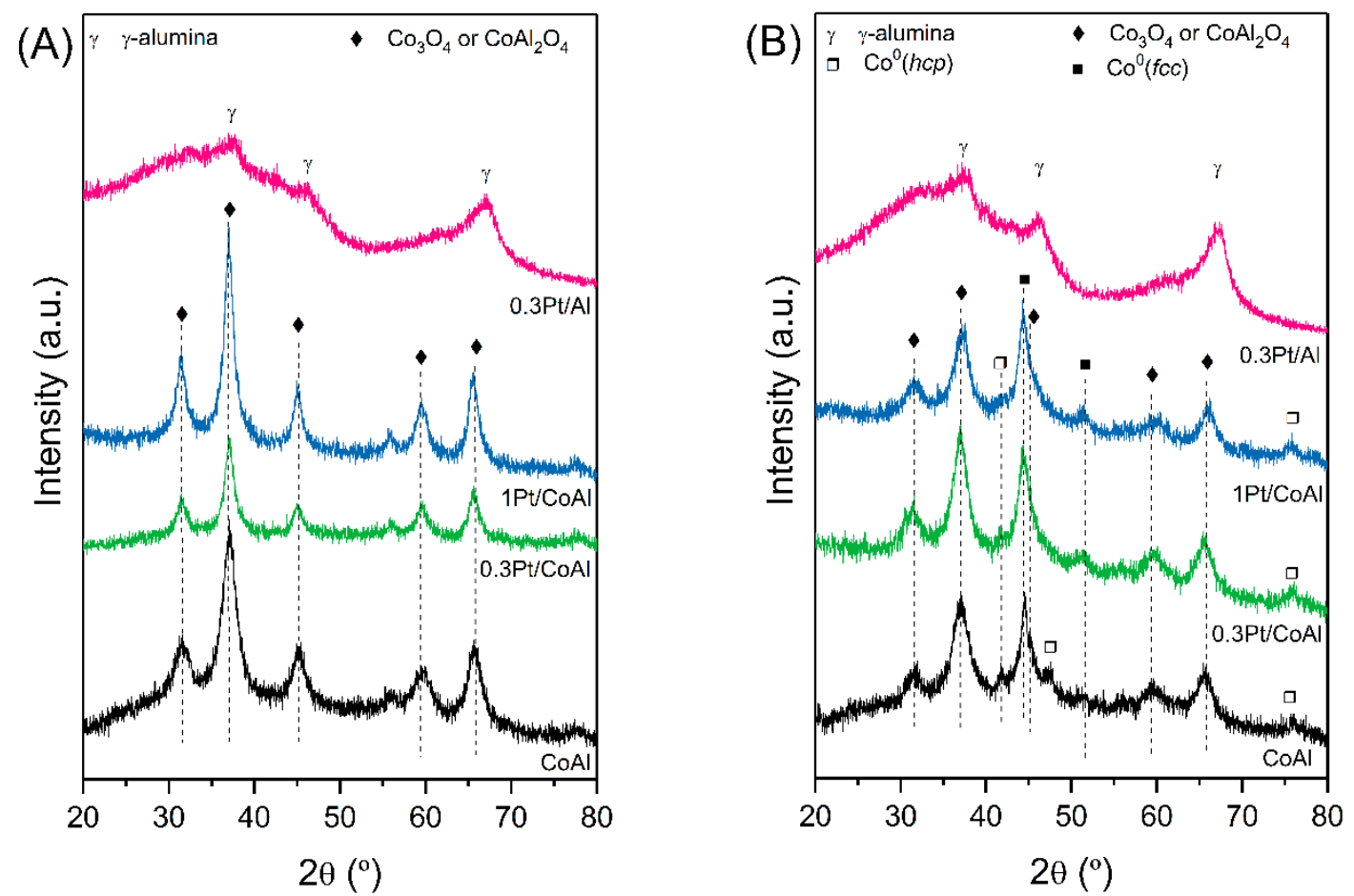

Figure 1. XRD patterns of (A) calcined and (B) reduced samples.

$\mathrm{H}_{2}$-TPR experiments were carried out in order to gain information about reducible species. The $\mathrm{H}_{2}$-TPR profiles of all the prepared catalysts are displayed in Figure 2 (due to its low intensity, the signal from $0.3 \mathrm{Pt} / \mathrm{Al}$ was five-fold magnified). The monometallic $0.3 \mathrm{Pt} / \mathrm{Al}$ sample showed three reduction peaks, of low intensity. The two low temperature peaks were related to the reduction of platinum species (PtOx). The peak at $227^{\circ} \mathrm{C}$ was attributed to the reduction of platinum species with low interaction with the alumina, and the one at $375^{\circ} \mathrm{C}$ to platinum species in close interaction with the support. The high temperature peak, at around $660^{\circ} \mathrm{C}$, was due to the reduction of alumina, assisted by the hydrogen spillover on $\mathrm{Pt}^{0}$ [25]. For the $\mathrm{CoAl}$ sample, the reduction peaks at 292 and $413^{\circ} \mathrm{C}$ came from the $\mathrm{Co}^{3+} \rightarrow \mathrm{Co}^{2+}$ reduction, the first of surface cobalt cations without interaction with the support and the latter from the $\mathrm{Co}^{3+}$ species in close interaction with the support. The peak at $594{ }^{\circ} \mathrm{C}$ was ascribed to $\mathrm{Co}^{2+} \rightarrow \mathrm{Co}^{0}$ reduction. Finally, the peak at $783{ }^{\circ} \mathrm{C}$ corresponded to the reduction of Co ions as cobalt aluminate $\left(\mathrm{CoAl}_{2} \mathrm{O}_{4}\right)$ [16]. Regarding bimetallic $\mathrm{xPt} / \mathrm{CoAl}$ samples, these presented four reduction peaks. The $\mathrm{H}_{2}$ uptake at low temperatures largely exceeded the theoretical hydrogen consumption of platinum species (Table 2$)$. Based on this, the peaks centered at $192{ }^{\circ} \mathrm{C}(0.3 \mathrm{Pt} / \mathrm{CoAl}$ ) and $157^{\circ} \mathrm{C}(1 \mathrm{Pt} / \mathrm{CoAl})$ were ascribed to the reduction of $\mathrm{PtO}_{\mathrm{x}}$ species alongside that of platinum-promoted (via hydrogen spillover) $\mathrm{Co}^{3+} \rightarrow \mathrm{Co}^{2+}$ reduction. As can be seen, the addition of Pt caused two different behaviors depending on its loading. On one hand, at the lowest loading $(0.3 \mathrm{wt} . \%)$, the presence of $\mathrm{Pt}$ decreased the $\mathrm{Co}^{2+} \rightarrow \mathrm{Co}^{0}$ reduction temperature from 594 to $563{ }^{\circ} \mathrm{C}$ and that of cobalt ions in the spinel phase from 783 to $736{ }^{\circ} \mathrm{C}$. Nevertheless, by increasing the Pt loading to $1 \mathrm{wt}$. $\%$, the reduction temperature of the aforementioned cobalt species increased by 74 and $84^{\circ} \mathrm{C}$, respectively. Thus, it could be concluded that the addition of $0.3 \mathrm{wt}$.\% $\mathrm{Pt}$ improved the reducibility of both metal species (Pt and $\mathrm{Co}$ ), as deduced from the increased low temperature hydrogen consumption and the amount of available metallic Co with respect to reference CoAl (Table 2). This promotional effect could be attributed to a strong Pt-Co interaction. The smaller size of $\mathrm{Co}^{0}$ in the bimetallic samples, as estimated by XRD, could be also involved. As expected, the amount of available metallic Pt sites increased proportionally to $\mathrm{Pt}$ loading - that is, Pt dispersion remained practically unchanged (as seen in Table 2). 


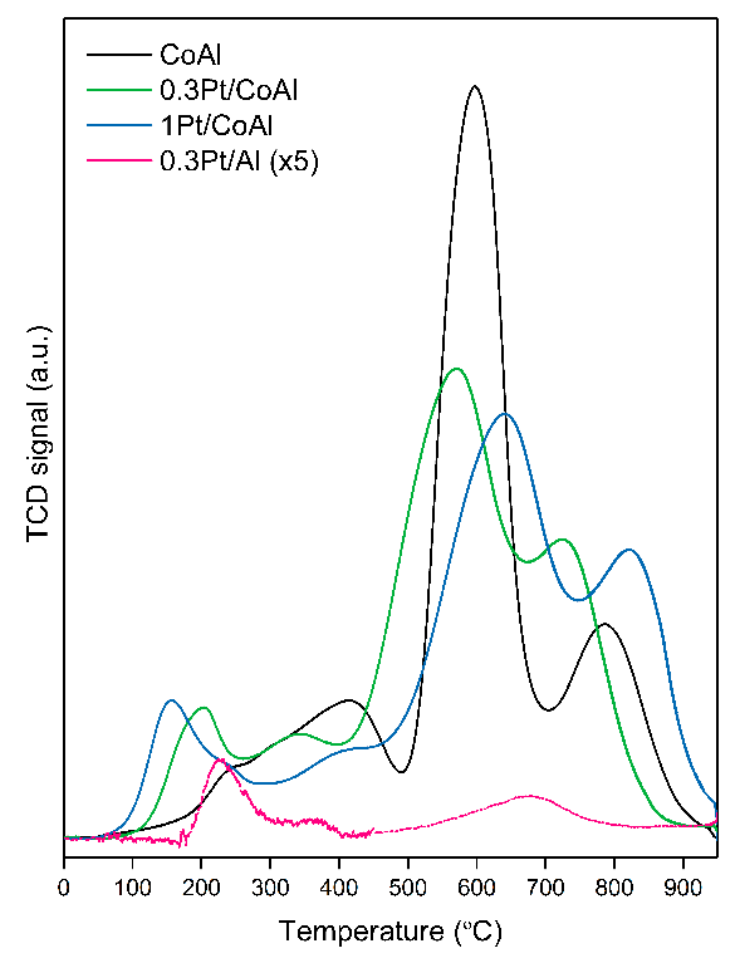

Figure 2. $\mathrm{H}_{2}$-TPR profiles of prepared samples.

Table 2. Results from $\mathrm{H}_{2}-\mathrm{TPR}, \mathrm{H}_{2}$ chemisorption and $\mathrm{CO}_{2}-\mathrm{TPD}$ studies.

\begin{tabular}{|c|c|c|c|c|c|c|c|}
\hline \multirow{2}{*}{ Catalyst } & \multicolumn{2}{|c|}{$\begin{array}{l}\mathrm{H}_{2} \text { Uptake } \\
\left(\mathrm{mmol}_{\mathrm{H} 2} / \mathrm{g}\right)\end{array}$} & \multicolumn{2}{|c|}{$\begin{array}{l}\text { Exposed Metal a } \\
\left.\text { (at.Pt } / g_{\text {cat }}\right)\end{array}$} & \multicolumn{2}{|c|}{$\mathrm{D}_{\mathrm{Pt}}(\%)$} & \multirow{2}{*}{$\begin{array}{l}\text { Surface Basic Sites Density } \\
{ }^{c}\left(\mu \mathrm{mol}{ }_{\mathrm{CO} 2} / \mathrm{m}^{2}\right)\end{array}$} \\
\hline & Total & Below $250^{\circ} \mathrm{C}$ & $\mathrm{Co}^{0}$ & $\mathbf{P t}^{0}$ & $\mathrm{H}_{2}$ Chem. $^{\mathrm{a}}$ & TEM $^{b}$ & \\
\hline $\mathrm{CoAl}$ & 7.04 & n.a. & $23.0 \cdot 10^{18}$ & 0 & n.d. & n.d. & 1.90 \\
\hline $0.3 \mathrm{Pt} / \mathrm{CoAl}$ & 7.29 & $0.516(0.0149)$ & $30.4 \cdot 10^{18}$ & $5.2 \cdot 10^{18}$ & 58 & 72 & 1.16 \\
\hline $1 \mathrm{Pt} / \mathrm{CoAl}$ & 7.36 & $0.659(0.0559)$ & $25.5 \cdot 10^{18}$ & $20.7 \cdot 10^{18}$ & 62 & 63 & 1.34 \\
\hline $0.3 \mathrm{Pt} / \mathrm{Al}$ & 0.35 & $0.0195(0.0185)$ & 0 & $6.9 \cdot 10^{18}$ & 62 & 64 & 0.32 \\
\hline
\end{tabular}

In parentheses is the theoretical amount assuming $\mathrm{PtO}$ species. ${ }^{a}$ from $\mathrm{H}_{2}$ pulse chemisorption. ${ }^{\mathrm{b}}$ determined by TEM analysis. ${ }^{c}$ from the sample mass gain in TGA.

The morphology of the reduced samples was investigated by scanning transmission electron microscopy (STEM) techniques. Figure 3 shows their corresponding STEM micrographs and the resulting particle size distribution histograms. The surface morphology of cobalt aluminate support is basically preserved after $\mathrm{Pt}$ addition. The analysis revealed the presence of well-dispersed metallic particles of homogeneous size, especially in Pt-containing catalysts. The overall particle size of metallic cobalt nanoparticles in the CoAl sample was in the range of $14-24 \mathrm{~nm}$, leading to an average size of $20.3 \mathrm{~nm}$, with a cube/cuboid shape. On the other hand, Pt nanoparticles were of near-spherical shape, with a much smaller size, in concordance with the absence of diffraction peaks in XRD. Pt nanoparticles ranged between 0.6 and $3.0 \mathrm{~nm}$, with an average size of $1.62 \mathrm{~nm}$ for $0.3 \mathrm{Pt} / \mathrm{CoAl}$ and $1.88 \mathrm{~nm}$ for 1Pt/CoAl. Pt nanoparticles were homogeneously dispersed onto larger Co nanoparticles (comparable with those observed in the CoAl catalyst), as can be seen in Figure 3B,C. For the monometallic $0.3 \mathrm{Pt} / \mathrm{Al}$ sample, most of the nanoparticles were uniform, with an average size of $1.84 \mathrm{~nm}$. The energy dispersive X-ray spectra (EDX) analysis (Figure S2, Supplementary Materials) confirmed the metallic composition of the Pt nanoparticles.

Platinum particle size was also calculated from $\mathrm{H}_{2}$ chemisorption, and a mean diameter of about $2.2 \mathrm{~nm}$ was measured for all the samples, which was slightly larger than the STEM calculated value. This discrepancy could be due to a limited hydrogen adsorption capacity due to strong Pt-Co interactions and likely alloy formation. The large discrepancy in the $0.3 \mathrm{Pt} / \mathrm{CoAl}$ catalyst suggested a stronger Pt-Co interaction, in agreement with $\mathrm{H}_{2}$-TPR. Pt dispersion was around $62 \%$ for the 
$1 \mathrm{Pt} / \mathrm{CoAl}$ and $0.3 \mathrm{Pt} / \mathrm{Al}$ samples and slightly lower $(58 \%)$ in catalyst $0.3 \mathrm{Pt} / \mathrm{CoAl}$. We hypothesize that the dispersion measured by $\mathrm{H}_{2}$ chemisorption for $0.3 \mathrm{Pt} / \mathrm{CoAl}$ was under-estimated due to the high Co-Pt interaction. In any case, it is worth noting the good agreement between the STEM and $\mathrm{H}_{2}$ chemisorption measured $\mathrm{Pt}$ dispersion data.
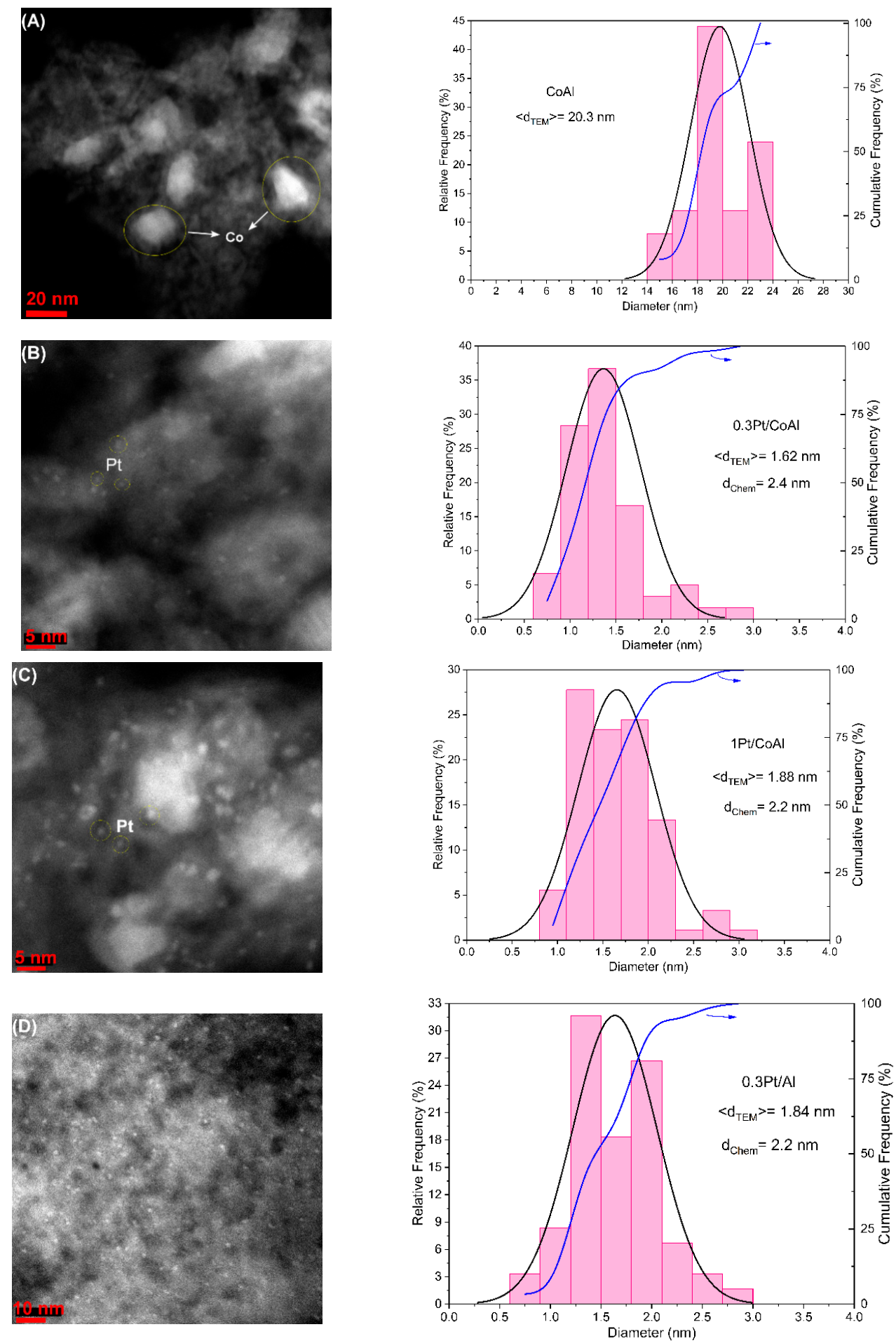

Figure 3. STEM micrographs and size distribution histogram of the reduced samples: (A) CoAl, (B) $0.3 \mathrm{Pt} / \mathrm{CoAl},(\mathbf{C}) 1 \mathrm{Pt} / \mathrm{CoAl}$ and $(\mathbf{D})$ 0.3Pt/Al.

The density of the surface basic sites of the reduced catalysts was evaluated by thermogravimetry, measuring the sample mass gain upon $\mathrm{CO}_{2}$ chemisorption. As reported in Table 2, the CoAl sample 
had the highest density of surface basic sites, with $1.90 \mu \mathrm{mol}_{\mathrm{CO} 2} / \mathrm{m}^{2}$. The $x \mathrm{Pt} / \mathrm{CoAl}$ series presented around $30 \%-40 \%$ lower density than monometallic CoAl. Among them, density slightly increased at $1 \mathrm{wt} . \% \mathrm{Pt}$ loading, whereas it was the lowest for catalyst $0.3 \mathrm{Pt} / \mathrm{Al}\left(0.32 \mu \mathrm{mol}_{\mathrm{CO} 2} / \mathrm{m}^{2}\right)$.

The effect of $\mathrm{Pt}$ addition on the distribution of Co species lying on the near-surface of the calcined and reduced samples was investigated by XPS. The binding energies (BE) of the $\mathrm{Al}, \mathrm{Co}$ and $\mathrm{Pt}$ species and the surface $\mathrm{Co} / \mathrm{Al}$ atomic ratios are reported in Table 3. The Co $2 \mathrm{p}$ and $\mathrm{Al} 2 \mathrm{p} \mathrm{X}$-ray photoelectron spectra for the reduced samples are shown in Figure $4\left(\mathrm{Pt}_{4} 4 \mathrm{~d}_{5 / 2}\right.$ spectra are given in Figure S3, Supplementary Materials). Prior to reduction, binding energies of $\mathrm{Al} 2 \mathrm{p}$ and Co $2 \mathrm{p}_{3 / 2}$ were significantly higher in CoAl than in Pt-impregnated catalysts. The higher values can be due to the strong interaction between aluminum and cobalt [26]. Upon reduction, all samples showed the characteristic Co $2 p$ doublet (Co $2 p_{3 / 2}$ and $\left.C_{0} 2 p_{1 / 2}\right)$ due to spin-orbit splitting. The spectra were deconvoluted into $\mathrm{Co}^{0}, \mathrm{Co}^{2+}$ and shake up satellites; however, no peaks could be assigned to $\mathrm{Co}^{3+}$, probably due to the self-reduction in the high vacuum chamber. Co $2 \mathrm{p}$ peaks of the $\mathrm{xPt} / \mathrm{CoAl}$ samples shifted to higher binding energies compared to parent CoAl. This upshift can be attributed to the electron transfer from less electronegative $\mathrm{Co}$ to $\mathrm{Pt}$ atoms that decreased electron density at the $\mathrm{Co}$ site [27]. The $\mathrm{Al} 2 \mathrm{p}$ peak at the binding energy of $74.2 \mathrm{eV}$ corresponded to $\mathrm{Al}$ cations placed at the octahedral sites [28]. As the strong $\mathrm{Al} 2 \mathrm{p}$ peak overlaps with the most prominent platinum electron line (Pt $4 \mathrm{f})$, the $\mathrm{Pt} 4 \mathrm{~d}_{5 / 2}$ was analyzed instead. Although limited due to the low platinum content, the spectra of $\mathrm{Pt} 4 \mathrm{~d}$ region showed peaks located at $314.0 \pm 0.2 \mathrm{eV}$ for the Pt-containing catalysts, which can be ascribed to the $\mathrm{Pt}^{0}$ phase [29].

Table 3. Binding energy values from XPS analysis.

\begin{tabular}{|c|c|c|c|c|c|c|}
\hline \multirow{2}{*}{ Catalyst } & \multirow{2}{*}{ Al 2p (ev) } & \multicolumn{2}{|c|}{$\operatorname{Co~} 2 \mathrm{p}_{3 / 2}(\mathrm{eV})$} & \multicolumn{2}{|c|}{$\mathrm{Pt} 4 \mathrm{~d}_{5 / 2}(\mathrm{eV})$} & \multirow{2}{*}{ Surface $\mathrm{Co} / \mathrm{Al}{ }^{a}$} \\
\hline & & $\mathrm{Co}^{2+}$ & $\mathrm{Co}^{0}$ & $\mathrm{Pt}^{2+}$ & $\mathbf{P t}^{0}$ & \\
\hline $\mathrm{CoAl}$ & $75.6(74.2)$ & $781.6(781.3)$ & n.d. (778.0) & n.a. & n.a. & $0.266(0.139)$ \\
\hline $0.3 \mathrm{Pt} / \mathrm{CoAl}$ & $74.2(74.2)$ & 781.1 (781.6) & n.d. (778.2) & 316.8 (n.d.) & n.d. (314.0) & $0.271(0.184)$ \\
\hline $1 \mathrm{Pt} / \mathrm{CoAl}$ & $74.2(74.2)$ & $781.2(781.5)$ & n.d. (778.2) & 317.7 (n.d.) & n.d. (314.2) & $0.271(0.186)$ \\
\hline $0.3 \mathrm{Pt} / \mathrm{Al}$ & $74.0(73.5)$ & n.d. & n.d. & 315.5 (n.d.) & n.d. (313.8) & n.d. \\
\hline
\end{tabular}

In parentheses are values for reduced samples. ${ }^{\text {a }}$ from XPS of calcined samples.
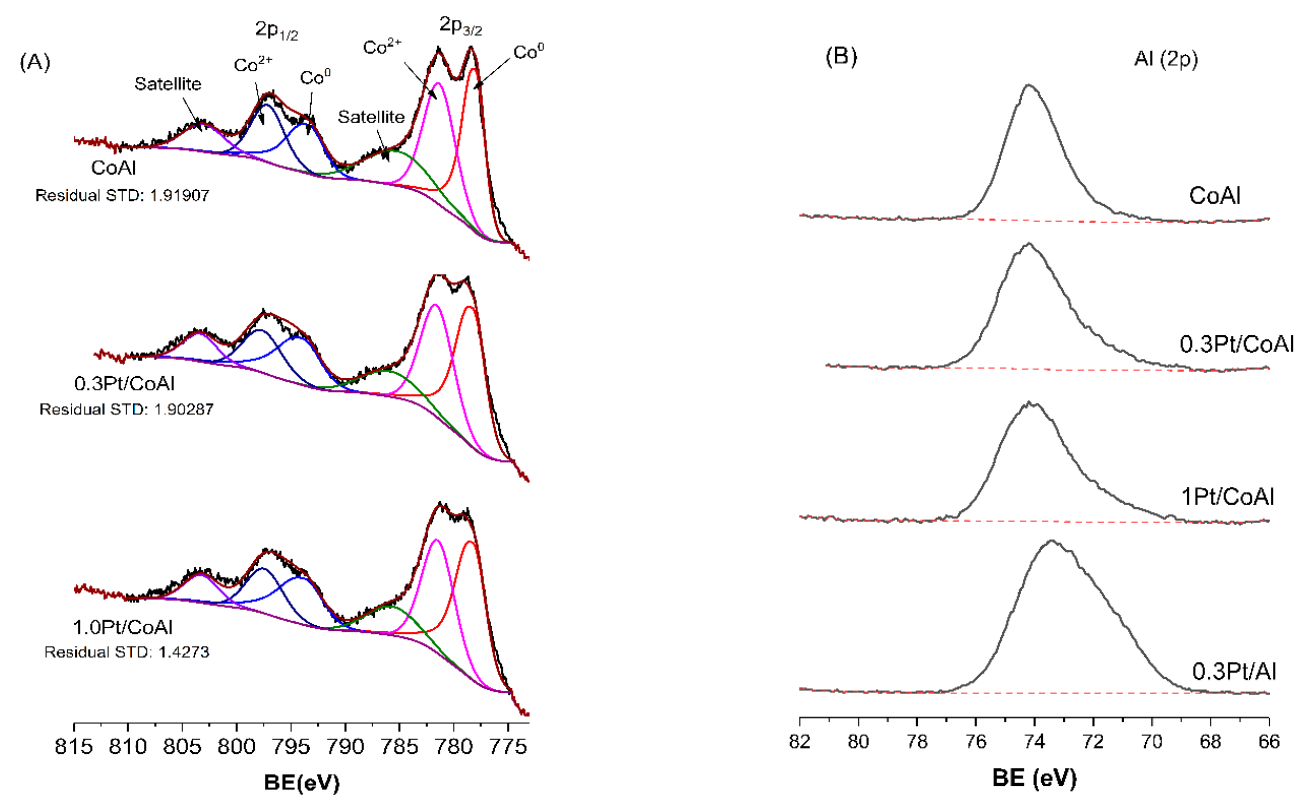

Figure 4. XPS spectra corresponding to (A) Co $2 p$ and (B) $\mathrm{Al} 2 \mathrm{p}$ for reduced samples.

The overall surface $\mathrm{Co} / \mathrm{Al}$ atomic ratio, calculated from $\mathrm{Co} 2 \mathrm{p}$ to $\mathrm{Al} 2 \mathrm{p}$ peak intensities (Table 3 ), decreased in comparison to bulk composition (evaluated by ICP-AES). This surface enrichment on $\mathrm{Al}^{3+}$ 
ions was attributed to the lower surface free energy of $\mathrm{Al}$ as compared to Co [30]. Upon reduction, the $\mathrm{Co} / \mathrm{Al}$ atomic ratio on surface decreased, probably due to the incorporation of metallic species into the porous structure [31], which would also explain the decrease in pore volume. Furthermore, it is interesting to note the higher $\mathrm{Co} / \mathrm{Al}$ values measured for the bimetallic assays (as compared to parent $\mathrm{CoAl})$, regardless of their calcined or reduced state.

\subsection{Liquid-Phase WGS Activity in the Absence of Hydrogen $\left(\mathrm{H}_{2} / \mathrm{CO}=0\right)$}

The WGS performance of the prepared catalysts was evaluated at $260{ }^{\circ} \mathrm{C}$ and 50 bar (which corresponded to 3.2 bar above saturation), with $\mathrm{H}_{2} \mathrm{O} / \mathrm{CO}=15 / 1$ mole ratio in the feedstream and a space-time of $76.8 \mathrm{~kg}_{\mathrm{cat}} \cdot \mathrm{s} / \mathrm{mol}_{\mathrm{CO}}$. The obtained $\mathrm{CO}$ conversion $\left(\mathrm{X}_{\mathrm{CO}}\right), \mathrm{CO}_{2}$ yield $\left(\mathrm{Y}_{\mathrm{CO} 2}\right)$ and $\mathrm{CH}_{4}$ yield $\left(\mathrm{Y}_{\mathrm{CH} 4}\right)$ at $10 \mathrm{~h}$ TOS are shown in Figure 5. Among all those tested, the monometallic 0.3Pt/Al catalyst exhibited the lowest activity in the aqueous-phase WGS, with a $29.9 \%$ conversion of CO. The platinum-free monometallic CoAl catalyst was the most active assay, with $51.2 \%$ conversion. Bimetallic catalysts performed better; thereby, after the addition of $0.3 \% \mathrm{Pt}$ to $\mathrm{CoAl}, \mathrm{CO}$ conversion increased to $63.8 \%$. Moreover, it was further improved by $1 \% \mathrm{Pt}$ loading, which reached $97.1 \%$ conversion, very close to thermodynamic equilibrium (98.8\%). It was evidenced that Pt loading on CoAl produced a promotional effect in the WGS activity and also confirmed the strong influence of the support on the catalytic behavior. The activation of the water molecule, a critical step in the WGS reaction, can occur either on the oxygen vacancies (reducible support) or on the metal particle. The $\mathrm{H}_{2}$-TPR results indicated the very low reducibility of the $0.3 \mathrm{Pt} / \mathrm{Al}$ catalysts, which suggested that the support did not provide sufficient oxygen vacancies for the activation of water molecules, as cobalt-containing catalysts did. Therefore, the WGS activity of the $0.3 \mathrm{Pt} / \mathrm{Al}$ catalyst should be related mainly to the available Pt particles, with competitive adsorption of both $\mathrm{CO}$ and $\mathrm{H}_{2} \mathrm{O}$. The apparent reaction rate, normalized per $\mathrm{Pt}$ site (on the $\mathrm{H}_{2}$ chemisorption basis), was calculated and was used to compare the WGS activity for both catalysts with similar Pt content $(0.3 \%)$. The obtained values $\left(0.31 \mathrm{~s}^{-1}\right.$ vs. $0.88 \mathrm{~s}^{-1}$ for $0.3 \mathrm{Pt} / \mathrm{Al}$ and $0.3 \mathrm{Pt} / \mathrm{CoAl}$, respectively) supported the hypothesis of the active participation of the support in the reaction mechanism. On the other hand, the apparent reaction rates normalized per $\mathrm{Co}$ site (based on $\mathrm{H}_{2}$ chemisorption) for the $\mathrm{CoAl}$ and $0.3 \mathrm{Pt} / \mathrm{CoAl}$ catalysts were very similar (around $0.16 \mathrm{~s}^{-1}$ ) and increased to $0.27 \mathrm{~s}^{-1}$ for the $1 \mathrm{Pt} / \mathrm{CoAl}$ catalyst.

The acid/basic character of the surface can also affect the WGS catalyst activity [12,32]. Among our samples, the surface basic site density of $0.3 \mathrm{Pt} / \mathrm{Al}\left(0.32 \mu \mathrm{mol}_{\mathrm{CO} 2} / \mathrm{m}^{2}\right)$ was lower than the cobalt-containing catalysts $\left(1.16-1.90 \mu \mathrm{mol}_{\mathrm{CO} 2} / \mathrm{m}^{2}\right)$. The basic sites can polarize the water molecule and induce its dissociation to hydroxyl [12], which is the kinetically limiting step in WGS. The excellent WGS catalytic performance of the Pt-Co ensemble was ascribed to its improved ability for water dissociation (by the alloyed cobalt surface) as well as by a lowered $\mathrm{CO}$ binding energy, in comparison to monometallic catalysts [33].

Two general mechanisms are commonly accepted for the gas-phase WGS reaction over noble metals supported on oxides: (i) regenerative mechanism, where the labile oxygen from the support oxidizes $\mathrm{CO}$ adsorbed on the metal and the formed oxygen vacancy is re-oxidized by water; (ii) associative mechanism, where adsorbed $\mathrm{CO}$ reacts with terminal hydroxyl groups of the support to form a C-containing intermediate that is decomposed to $\mathrm{CO}_{2}$ and $\mathrm{H}_{2}$. Thus, both the dispersed metal and the support participate in the reaction. Figure 6 depicts the schematic representation of the WGS reaction when water reacts from the vapor or liquid phase. Davda et al. [10] contemplated the idea that WGS occurred in the gas bubbles formed within the liquid-phase reactor (scheme A), with the vapor water amount dictated by its liquid-vapor saturation. In scheme B, water reacts from the liquid phase and $\mathrm{CO}$ reacts from the gas phase, which implies that the reaction takes place at the gas-liquid-solid interface [14]. In both schemes, the CO reactant and the obtained products were partially dissolved in liquid water, dictated by the vapor/solution equilibrium (Henry's law). Partial pressures of water, $\mathrm{CO}$ and $\mathrm{H}_{2}$, and the liquid/gas distribution of $\mathrm{CO}$ and $\mathrm{H}_{2}$ for each experiment, are given in Table S2, 
Supplementary Materials. As can be seen, the very high partial pressure of water, close to the operation pressure, has a large impact on the $\mathrm{CO}$ and $\mathrm{H}_{2}$ partial pressures, which are very low.

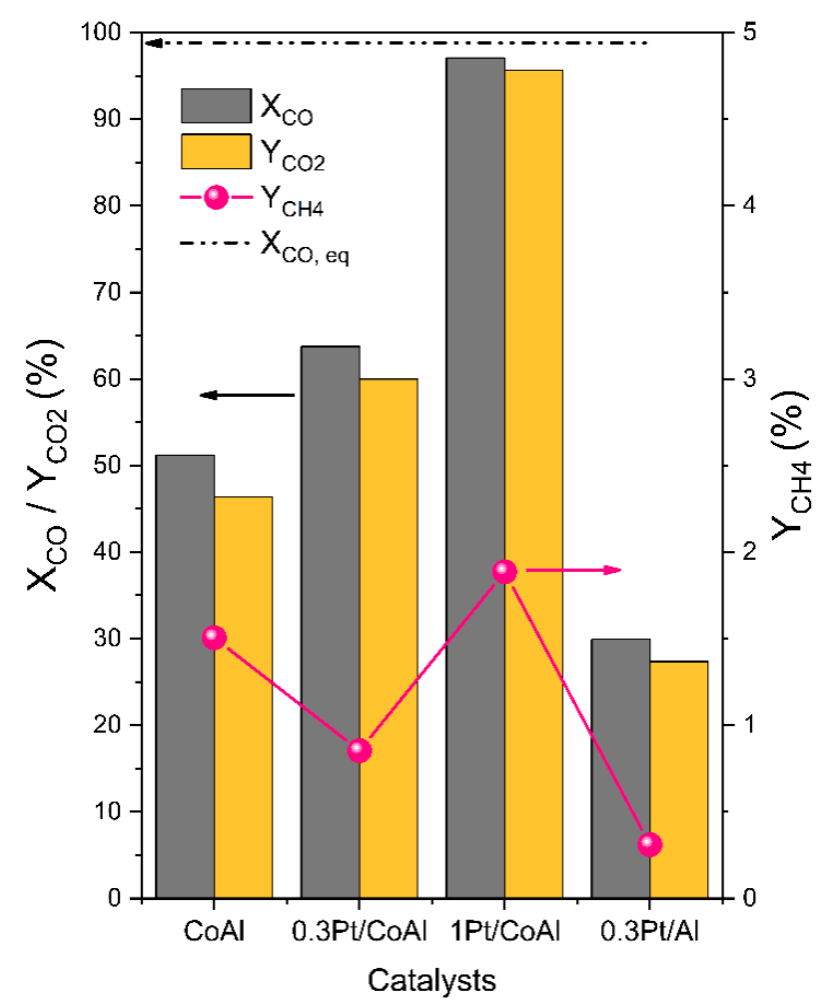

Figure 5. CO conversion and product yields in liquid phase WGS reaction at $260^{\circ} \mathrm{C} / 50$ bar and TOS $=\mathrm{t}$ 10 h. Feedstream: $\mathrm{H}_{2} \mathrm{O} / \mathrm{CO}=15 / 1 \mathrm{~mol}$ ratio, space-time $=76.8 \mathrm{~kg}_{\mathrm{cat}} \cdot \mathrm{s} / \mathrm{mol}_{\mathrm{CO}}$.

(A)

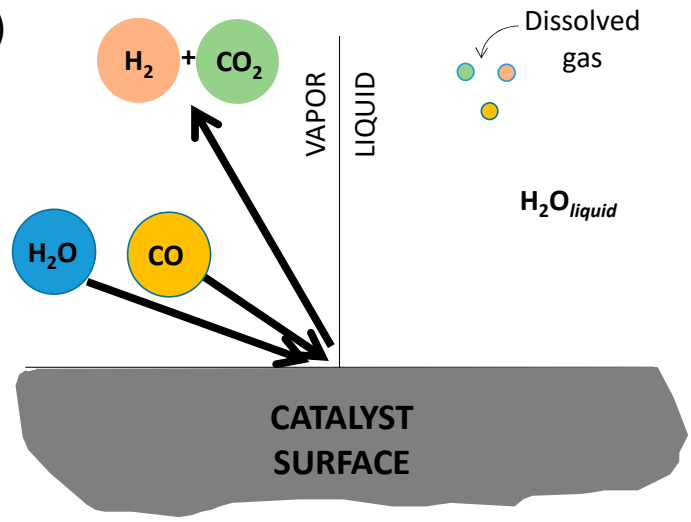

(B)

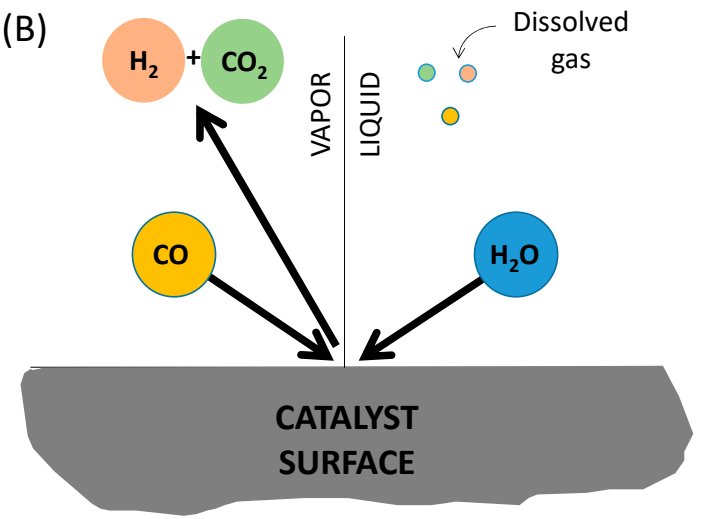

Figure 6. Schematic representation of the water-gas shift (WGS) reaction mechanisms for aqueous-phase reforming (APR) reacting $\mathrm{H}_{2} \mathrm{O}$ from liquid (A) or vapor (B) phase.

Under the investigated operation conditions, all the catalysts showed high $\mathrm{CO}_{2}$ yield (ranging from $27.4 \%$ for $0.3 \mathrm{Pt} / \mathrm{Al}$ to $95.7 \%$ for $1 \mathrm{Pt} / \mathrm{CoAl}$ ). Moreover, $\mathrm{CO}_{2}$ selectivity was above $90 \%$ for all the catalysts. Thus, the $\mathrm{CO}_{2}$ yields indicated a satisfactory product distribution, with mainly $\mathrm{H}_{2}$ and $\mathrm{CO}_{2}$ in the gas product stream. Methane was also detected, though to a much lesser extent. Methane yield increased as follows: $0.3 \mathrm{Pt} / \mathrm{Al}(0.3 \%)<0.3 \mathrm{Pt} / \mathrm{CoAl}(0.9 \%)<\operatorname{CoAl}(1.5 \%)<1 \mathrm{Pt} / \mathrm{CoAl}(1.9 \%)$.

Two mechanisms are usually proposed for $\mathrm{CO}$ hydrogenation: (i) associative, where carbonyl combines with $\mathrm{H}_{\text {ads }}$ followed by $\mathrm{C}-\mathrm{O}$ bond cleavage, and (ii) dissociative, where $\mathrm{C}-\mathrm{O}$ bond breaking takes place directly on the metal, before the hydrogenation step [34]. Under the investigated conditions (i.e., feedstream containing only $\mathrm{CO}$ and water), the negligible hydrogenation of $\mathrm{CO}$ was associated 
with the low availability of the in-situ produced hydrogen that, in fact, competed for the metal sites. Moreover, not all the hydrogen produced in the gas phase was readily available for CO hydrogenation, as it was partly dissolved in the aqueous phase. The Henry's constants in Section 3.2 indicate the higher solubility of hydrogen gas as compared to $\mathrm{CO}$. Nevertheless, the fraction of $\mathrm{CO}$ and $\mathrm{H}_{2}$ dissolved in the liquid phase was four orders of magnitude lower than that remaining in the liquid phase (see Table S2, Supplementary Materials). This was reflected in the large $\mathrm{Y}_{\mathrm{CO} 2} / \mathrm{Y}_{\mathrm{CH} 4}$ yields ratio for all the samples (Table 4), between 30.8 (for $\mathrm{CoAl}$ ) and 88.1 (for 0.3Pt/Al), indicating the superior $\mathrm{CO}$ hydrogenation activity of cobalt in a hydrogen-lean scenario. Further investigation was carried out to simulate real APR operation conditions (high $\mathrm{H}_{2} / \mathrm{CO}$ ratio) and elucidate whether high hydrogen availability could overcome such $\mathrm{CO}$ hydrogenation limitations. The results are presented in the following section.

Table 4. $\mathrm{Y}_{\mathrm{CO} 2} / \mathrm{Y}_{\mathrm{CH} 4}$ yields ratio for all the experiments.

\begin{tabular}{|c|c|c|c|c|c|c|c|c|}
\hline \multirow{3}{*}{ Catalyst } & \multirow{2}{*}{\multicolumn{4}{|c|}{$\begin{array}{c}\text { Effect of Feedstock } \\
\mathrm{H}_{2} / \mathrm{CO} \text { Ratio }\end{array}$}} & \multicolumn{2}{|c|}{$\begin{array}{l}\text { Temperature Effect } \\
\text { (@ } 50 \text { bar) }\end{array}$} & \multicolumn{2}{|c|}{$\begin{array}{l}\text { Pressure Effect } \\
\left(@ 260^{\circ} \mathrm{C}\right)\end{array}$} \\
\hline & & & & & \multirow{2}{*}{$\begin{array}{c}\text { Temperature } \\
\left({ }^{\circ} \mathrm{C}\right)\end{array}$} & \multirow{2}{*}{$\begin{array}{c}\mathrm{Y}_{\mathrm{CO} 2} / \mathrm{Y}_{\mathrm{CH} 4} \text { for } \\
0.3 \mathrm{Pt} / \mathrm{CoAl}\end{array}$} & \multirow{2}{*}{ Pressure (bar) } & \multirow{2}{*}{$\begin{array}{c}\mathrm{Y}_{\mathrm{CO} 2} / \mathrm{Y}_{\mathrm{CH} 4} \text { fo } \\
0.3 \mathrm{Pt} / \mathrm{CoAl}\end{array}$} \\
\hline & 0 & $4 / 3$ & $7 / 3$ & $12 / 3$ & & & & \\
\hline CoAl & 30.8 & 8.5 & 6.7 & 4.6 & 220 & 0.97 & 25 & 8.2 \\
\hline $0.3 \mathrm{Pt} / \mathrm{CoAl}$ & 70.3 & 70.7 & 12.2 & 11.0 & 235 & 3.5 & 35 & 2.4 \\
\hline $1 \mathrm{Pt} / \mathrm{CoAl}$ & 50.7 & 62.4 & 21.7 & 21.9 & 245 & 6.0 & 40 & 2.1 \\
\hline $0.3 \mathrm{Pt} / \mathrm{Al}$ & 88.1 & 131.7 & 106.7 & 59.4 & 260 & 11.0 & 50 & 0.97 \\
\hline
\end{tabular}

\subsection{Liquid-Phase WGS Activity in the Presence of Hydrogen $\left(\mathrm{H}_{2} / \mathrm{CO}>0\right)$}

In order to investigate the $\mathrm{CO}$ hydrogenation capacity of the catalysts under real APR conditions, $\mathrm{H}_{2}$ was co-fed at different $\mathrm{H}_{2} / \mathrm{CO}$ mole ratios (4/3, 7/3 and 12/3). The investigated $\mathrm{H}_{2} / \mathrm{CO}$ ratios were established based on the stoichiometric ratio in a typical APR process. Figure 7A displays the reached $\mathrm{CO}$ conversion as a function of the $\mathrm{H}_{2} / \mathrm{CO}$ ratio for all the catalysts assayed, evaluated at $260{ }^{\circ} \mathrm{C}$ and 50 bar after $10 \mathrm{~h}$ TOS. For comparison purposes, the $X_{\mathrm{CO}}$ values attained for the hydrogen-free feedstream are also depicted $\left(\mathrm{H}_{2} / \mathrm{CO}=0\right)$. For all the catalysts, the achieved $\mathrm{CO}$ conversion was lower than that obtained in the absence of hydrogen in the feedstream. Additionally, a decreasing trend of $\mathrm{XcO}$ with $\mathrm{H}_{2} / \mathrm{CO}$ was observed. The figure shows that bimetallic $x \mathrm{Pt} / \mathrm{CoAl}$ catalysts remained as the most active, independent of the $\mathrm{H}_{2} / \mathrm{CO}$ ratio. The achieved $\mathrm{CO}$ conversion values varied as follows: $1 \mathrm{Pt} / \mathrm{CoAl}>>0.3 \mathrm{Pt} / \mathrm{CoAl}>>\mathrm{CoAl}>0.3 \mathrm{Pt} / \mathrm{Al}$. It is interesting to note that the monometallic CoAl catalyst was the most sensitive to the feedstream composition (it had the largest negative slope in the figure). Catalyst $\mathrm{CoAl}$ showed the major drop, of around $50 \%\left(\mathrm{X}_{\mathrm{CO}}=39.4 \%\right.$ and dropped to $19.9 \%$ by passing from $\mathrm{H}_{2} / \mathrm{CO}=4 / 3$ to $\left.12 / 3\right)$. The decrease was quite similar for $0.3 \mathrm{Pt} / \mathrm{Al}(29 \%)$ and $0.3 \mathrm{Pt} / \mathrm{CoAl}(25 \%)$ catalysts. As noted, $1 \mathrm{Pt} / \mathrm{CoAl}$ was the least sensitive to $\mathrm{H}_{2} / \mathrm{CO}$ ratio, with only an $11 \%$ decrease in $\mathrm{X}_{\mathrm{CO}}$. A possible explanation of the negative effect of $\mathrm{H}_{2} / \mathrm{CO}$ ratio on $\mathrm{X}_{\mathrm{co}}$ could be the lower residence time of the gas phase (as $\mathrm{H}_{2} / \mathrm{CO}$ increased) and the competition between $\mathrm{H}_{2}$ and $\mathrm{CO}$ for the available metal sites. In addition, the higher $\mathrm{H}_{2} / \mathrm{CO}$ ratio decreased the $\mathrm{CO}$ partial pressure, which also might negatively affect the reaction rate. At these reaction conditions, $\mathrm{CO}$ was converted by both the WGS and CO hydrogenation reactions. It is known that $\mathrm{CO}$ poses a negative reaction order in the methanation reaction, whereas it is slightly positive for $\mathrm{H}_{2}$ [35]. The apparent reaction order with respect to $\mathrm{CO}$ was positive for all the catalysts and ranged between 0.12 and 0.17 for the bimetallic catalysts and 0.57 for the monometallic CoAl catalyst, while the order with respect to $\mathrm{H}_{2}$ was neatly negative (between -0.34 and -0.80 for bimetallic catalysts).

Regarding product distribution, unreacted $\mathrm{H}_{2}$ and $\mathrm{CO}$, together with produced $\mathrm{CO}_{2}, \mathrm{CH}_{4}$ and traces of ethane, were detected in the reactor outlet. The very low production of $\mathrm{C}_{2+}$ alkanes indicated the low Fisher-Tropsch activity of our catalysts at these reaction conditions. Indeed, the production of methane was notably higher than under the hydrogen-free feed conditions, except for the 0.3Pt/Al catalysts, for which it slightly decreased. Several studies have shown that in the gas phase, the CO hydrogenation rate is higher than $\mathrm{CO}_{2}$ hydrogenation, evidencing that high concentrations of $\mathrm{CO}$ in the reaction bed could inhibit the reaction of $\mathrm{CO}_{2}$ [34]. On this basis, we assumed that methane 
was only formed from $\mathrm{CO}$ hydrogenation. In this scenario, $\mathrm{CO}$ was consumed by both WGS and $\mathrm{CO}$ hydrogenation reactions. Figure 7B shows the trend in the $\mathrm{CO}_{2}$ and $\mathrm{CH}_{4}$ yields with $\mathrm{H}_{2} / \mathrm{CO}$ ratio. The $\mathrm{CO}_{2}$ yield showed a similar decreasing trend to $\mathrm{X}_{\mathrm{CO}}$. As occurred for $\mathrm{H}_{2} / \mathrm{CO}=0$ (hydrogen was not fed), the bimetallic $x \mathrm{Pt} / \mathrm{CoAl}$ catalysts remained the most selective to $\mathrm{CO}_{2}$, independent of the $\mathrm{H}_{2} / \mathrm{CO}$ ratio, while both monometallic catalysts showed similar values of $\mathrm{Y}_{\mathrm{CO} 2}$, especially at $\mathrm{H}_{2} / \mathrm{CO} \geq 7 / 3$.
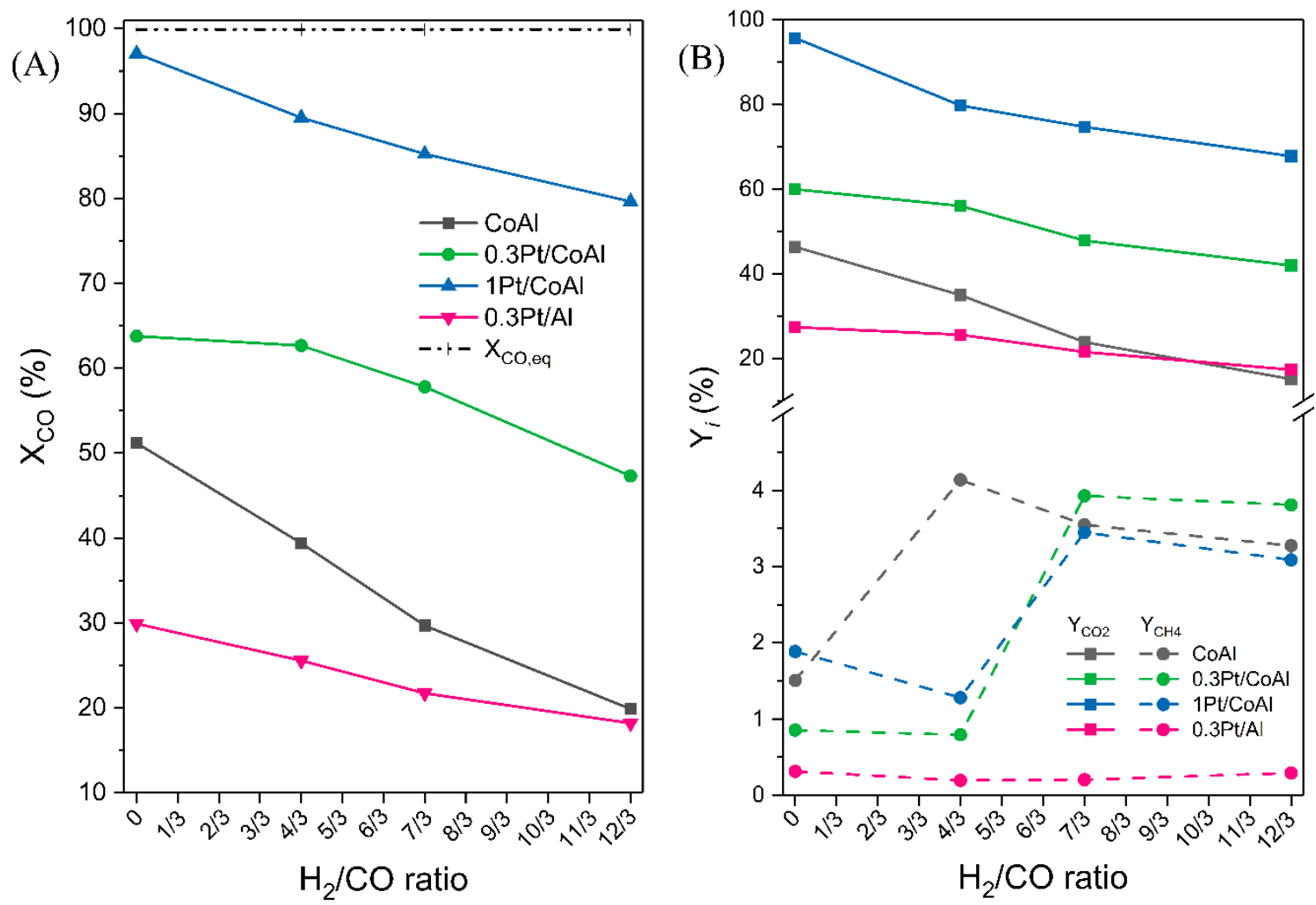

Figure 7. Catalytic activity in the WGS reaction at $260^{\circ} \mathrm{C} / 50$ bar and $\mathrm{H}_{2}$ co-feeding: (A) $\mathrm{CO}$ conversion and $(B)$ product yield. Reaction conditions: $\mathrm{W}_{\text {cat }}=0.2 \mathrm{~g}, \mathrm{~F}_{\mathrm{H} 2 \mathrm{O}}=0.04 \mathrm{~mL} / \mathrm{min}, \mathrm{F}_{\mathrm{CO}}=3.5 \mathrm{~mL} / \mathrm{min}$.

Methane yield $\left(\mathrm{Y}_{\mathrm{CH} 4}\right)$ was used as representative of the $\mathrm{CO}$ hydrogenation activity. The results in Figure 7B clearly evidence that hydrogenation activity was more pronounced for Co-containing catalysts, in agreement with the literature [36]. Not in vain, cobalt is one of the most used catalysts for $\mathrm{CO}$ hydrogenation [37]. On the opposite side, the $0.3 \mathrm{Pt} / \mathrm{Al}$ catalyst showed very low $\mathrm{Y}_{\mathrm{CH} 4}$. For example, at the highest $\mathrm{H}_{2} / \mathrm{CO}$ ratio of $12 / 3$, catalyst $0.3 \mathrm{Pt} / \mathrm{Al}$ showed $0.29 \%$ of methane yield, whereas the rest of the investigated catalysts ranged in the $3.1 \%-3.8 \%$ interval. Among the cobalt-containing catalysts, the different behavior of $\mathrm{Y}_{\mathrm{CH} 4}$ for the monometallic $\mathrm{CoAl}$ is noticeable when changing $\mathrm{H}_{2} / \mathrm{CO}$ from 0 to $4 / 3$ - that is, for bimetallic catalysts, methane yield slightly decreased as $\mathrm{H}_{2}$ availability increased, while for the CoAl catalyst, methane yield was boosted. This behavior could be related to the size of the cobalt particles, which was two-fold larger in the monometallic sample. Indeed, the hydrogenation of $\mathrm{CO}$ is known to be favored onto large cobalt particles [38]. Note that, even in the case of more available hydrogen (higher $\mathrm{H}_{2} / \mathrm{CO}$ ), $\mathrm{Y}_{\mathrm{CH} 4}$ reached a plateau for the bimetallic catalysts. The effect on $\mathrm{Y}_{\mathrm{CH} 4}$ of the $\mathrm{H}_{2} / \mathrm{CO}$ ratio change from $4 / 3$ to $7 / 3$ for cobalt-containing catalysts was also noticeable and could be related to the formation of cobalt carbide-like species at low hydrogen partial pressures [39].

As previously noted, we assumed that the $\mathrm{CO}_{2}$ hydrogenation rate was negligible with respect to $\mathrm{CO}$ hydrogenation. In addition, no carbon deposits were detected in the spent catalysts. Therefore, the yield ratio $\left(\mathrm{Y}_{\mathrm{CO} 2} / \mathrm{Y}_{\mathrm{CH} 4}\right)$ could be assumed as representative of the selectivity to WGS reaction (instead of $\mathrm{CO}$ hydrogenation): higher $\mathrm{Y}_{\mathrm{CO} 2} / \mathrm{Y}_{\mathrm{CH} 4}$ indicated higher selectivity to WGS-that is, the $\mathrm{CO}$ was converted preferably by WGS rather than by CO hydrogenation. Table 4 shows the obtained 
$\mathrm{Y}_{\mathrm{CO} 2} / \mathrm{Y}_{\mathrm{CH} 4}$ values. Regardless of the catalyst, selectivity to WGS decreased with increasing hydrogen concentration in the feed, as more hydrogen is available for hydrogenation. It is interesting to note that the bimetallic $x \mathrm{Pt} / \mathrm{CoAl}$ catalysts experienced the highest drop in $\mathrm{Y}_{\mathrm{CO} 2} / \mathrm{Y}_{\mathrm{CH} 4}$ values $(84.4 \%$ and $64.9 \%$ for 0.3 and $1 \% \mathrm{Pt}$ loading, respectively), as can be seen in Table 4 . Even so, they presented high WGS activity, only surpassed by the monometallic Pt sample.

Net hydrogen change $\left(\Delta \mathrm{H}_{2}\right)$ has been defined as the difference in hydrogen molar flow between the reactor outlet and inlet: it can be either positive or negative depending on the net generation or consumption of hydrogen in the reaction system. In addition, the $\Delta \mathrm{H}_{2}$ parameter reflects the hydrogenation activity. CO hydrogenation (methanation) is a highly hydrogen-consuming reaction and pulls the $\Delta \mathrm{H}_{2}$ parameter to negative values. As can be seen in Figure 8, for cobalt-containing catalysts, $\Delta \mathrm{H}_{2}$ decreased with the increase of $\mathrm{H}_{2} / \mathrm{CO}$, due to the hydrogenation capability of cobalt, boosted by the hydrogen excess. Among all catalysts, both bimetallic xPt/CoAl catalysts presented positive $\Delta \mathrm{H}_{2}$, independent of the $\mathrm{H}_{2} / \mathrm{CO}$ used. The largest positive $\Delta \mathrm{H}_{2}$ corresponded to the bimetallic $1 \mathrm{Pt} / \mathrm{CoAl}$ catalysts, in agreement with its highest activity and selectivity to the WGS reaction, with a maximum value of $33.9 \%$ for $\mathrm{H}_{2} / \mathrm{CO}=4 / 3$. Catalyst $0.3 \mathrm{Pt} / \mathrm{Al}$ presented slightly negative $\Delta \mathrm{H}_{2}$ at a low $\mathrm{H}_{2} / \mathrm{CO}$ ratio $\left(-1.02 \%\right.$ at $\left.\mathrm{H}_{2} / \mathrm{CO}=4 / 3\right)$, which turned slightly positive $(+0.52 \%)$ for the highest hydrogen to $\mathrm{CO}$ mole ratio.

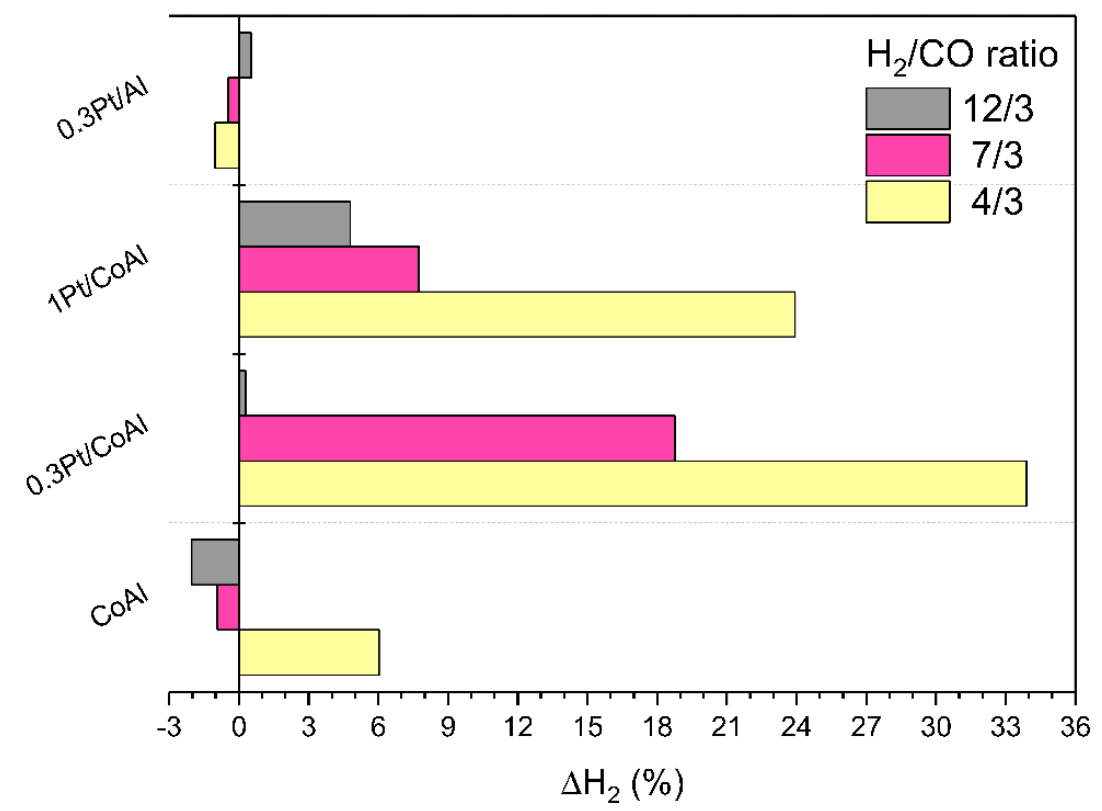

Figure 8. Net hydrogen variation in WGS reaction feeding $\mathrm{H}_{2}$ at $260{ }^{\circ} \mathrm{C} / 50$ bar. Reaction conditions: $\mathrm{W}_{\text {cat }}=0.2 \mathrm{~g}, \mathrm{~F}_{\mathrm{H} 2 \mathrm{O}}=0.04 \mathrm{~mL} / \mathrm{min}, \mathrm{F}_{\mathrm{CO}}=3.5 \mathrm{~mL} / \mathrm{min}$.

\subsection{Effect of Temperature and Pressure}

Both the reaction temperature and pressure have a strong influence on the polyol APR activity and product distribution [40]. Whether the effect is related to reforming or to WGS is of great interest in order to understand the APR behavior. With this aim, further experiments were carried out with catalyst $0.3 \mathrm{Pt} / \mathrm{CoAl}$ in order to investigate the influence of temperature and pressure on the WGS activity and with $\mathrm{H}_{2}$ co-feeding. Figure 9A shows the $\mathrm{CO}$ conversion achieved at 50 bar at different reaction temperatures, at $\mathrm{H}_{2} / \mathrm{CO}=12 / 3$. The observed initial increase in the conversion (which lasted about $3 \mathrm{~h}$ ) was due to unsteady operation due to the reaction protocol, where the temperature was ramped while holding pressure. Thereafter, the conversion of CO remained stable. Noticeably, the increase in the reaction temperature led to increased $\mathrm{CO}$ conversion values. However, the obtained values were far from the equilibrium (given in Figure 9), indicating a kinetically controlled reaction regime under these operation conditions. At low reaction temperatures, the higher overpressure may play a negative 
role in the catalytic activity, as the product's desorption from the catalyst surface was hindered [41]. In addition, the water solubility of the reactants $\left(\mathrm{CO}\right.$ and $\left.\mathrm{H}_{2}\right)$ increased according to Henry's law $(\mathrm{H}$ constants from Section 3.2). The fact that these values barely varied with temperature (from 2.2 at $220^{\circ} \mathrm{C}$ to 2.5 at $260^{\circ} \mathrm{C}$ ) suggested that solubility issues hardly affected the $\mathrm{H}_{2} / \mathrm{CO}$ mole ratio in the gas phase (see Table S2 in Supplementary Materials). According to Table 4, the $\mathrm{Y}_{\mathrm{CO} 2} / \mathrm{Y}_{\mathrm{CH} 4}$ ratio increased with the operation temperature, i.e., it became more selective to WGS. This trend could be explained by two reasons: firstly, the thermodynamics of the $\mathrm{CO}$ hydrogenation reaction (highly exothermic reaction), which is highly favorable at lower temperatures; secondly, the increased partial pressure of water in the gas phase, which would shift the WGS equilibrium towards the products.
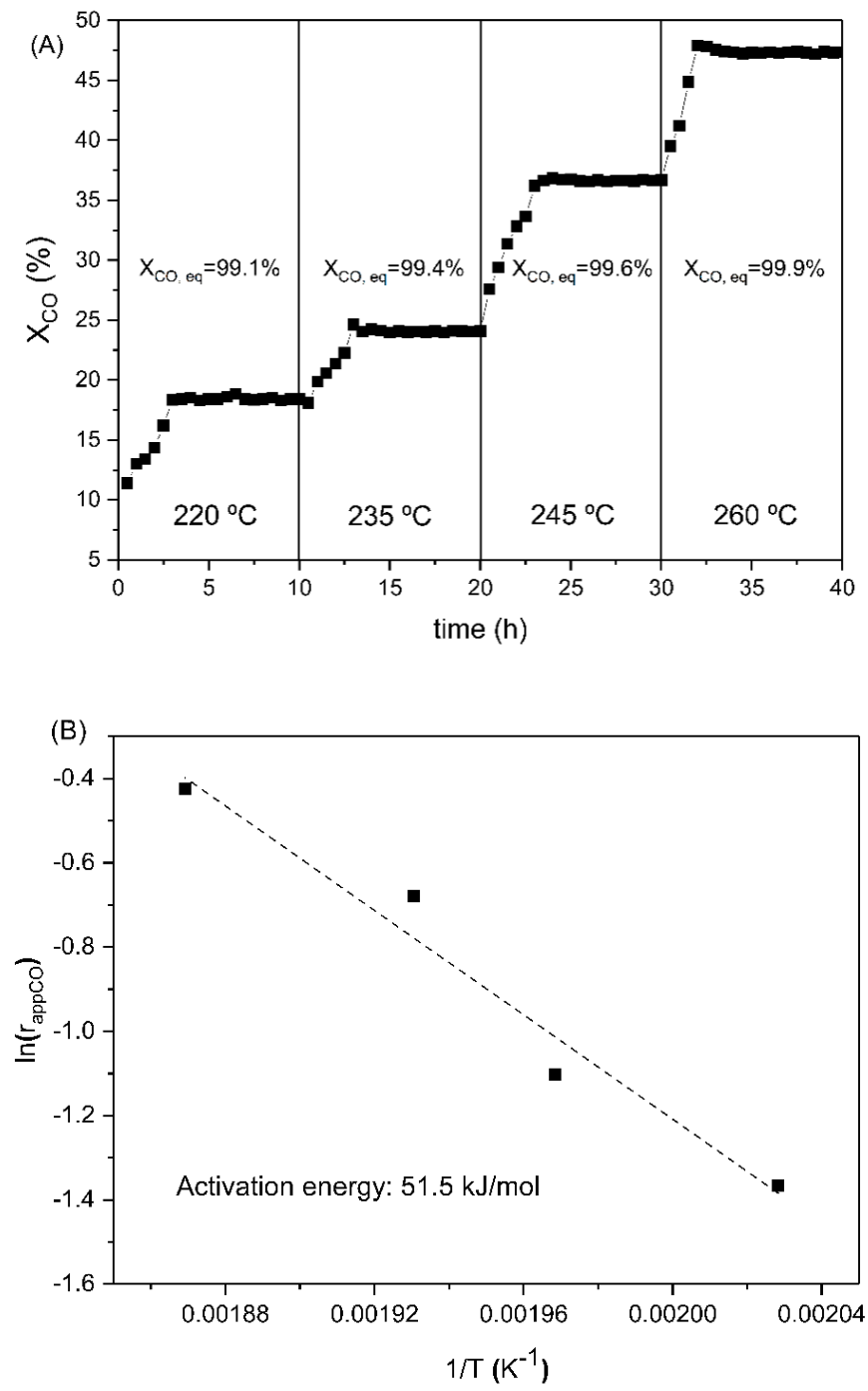

Figure 9. (A) Conversion of $\mathrm{CO}$ in WGS reaction feeding $\mathrm{H}_{2}$ over $0.3 \mathrm{Pt} / \mathrm{CoAl}$ catalyst at 50 bar; (B) Arrhenius plot. Reaction conditions: $\mathrm{W}_{\text {cat }}=0.2 \mathrm{~g}, \mathrm{~F}_{\mathrm{H} 2 \mathrm{O}}=0.04 \mathrm{~mL} / \mathrm{min}, \mathrm{F}_{\mathrm{CO}}=3.5 \mathrm{~mL} / \mathrm{min}$, $\mathrm{F}_{\mathrm{H} 2}=14 \mathrm{~mL} / \mathrm{min}$.

The apparent reaction rate normalized per $\mathrm{Pt}$ site $\left(\mathrm{r}_{\mathrm{app}}, \mathrm{co}\right)$ (on the $\mathrm{H}_{2}$ chemisorption basis) was calculated for each reaction temperature, at 50 bar and $\mathrm{H}_{2} / \mathrm{CO}=12 / 3$ in the feedstream. Obtained values are shown in Table 5, and they revealed that $\mathrm{r}_{\mathrm{app}}$, co was strongly affected by the reaction temperature, as supported by the activation energy value of $51.5 \mathrm{~kJ} / \mathrm{mol}$ calculated from the Arrhenius plot (Figure 9B). To our knowledge, this is the first approach to the experimental determination of the apparent activation energy for the liquid-phase WGS. For comparison purposes, the apparent activation energy values reported in the literature for Pt catalysts are shown in Table S1 (Supplementary Materials). It is of 
interest to note the inhibitory effect of hydrogen on the intrinsic reaction rate, as $\mathrm{r}_{\mathrm{app}}$, co decreased from 0.88 (for hydrogen-free feedstream) to $0.654 \mathrm{~s}^{-1}$ (for $\mathrm{H}_{2} / \mathrm{CO}=12 / 3$ ).

Table 5. Apparent reaction rate normalized per $\mathrm{Pt}$ site $\left(\mathrm{r}_{\mathrm{app}}, \mathrm{co}\right)$ on the $\mathrm{H}_{2}$ chemisorption basis.

\begin{tabular}{cc}
\hline Temperature $\left({ }^{\circ} \mathbf{C}\right)$ & $\mathbf{r}_{\mathbf{a p p}}, \mathbf{c o}\left(\mathbf{s}^{\mathbf{- 1}}\right)$ \\
\hline 220 & 0.255 \\
235 & 0.332 \\
245 & 0.507 \\
260 & 0.654 \\
\hline
\end{tabular}

Figure 10 shows $\mathrm{CO}$ conversion at $220^{\circ} \mathrm{C}$ for different reaction pressures, with $\mathrm{H}_{2} / \mathrm{CO}=12 / 3$. The observed gap in the first $2.5 \mathrm{~h}$ of reaction at each pressure is because the reactor outlet flow valve was shut until the desired pressure was achieved. Notably, CO conversion increased with operation pressure, at a constant reaction temperature. For example, at 25 bar, the obtained CO conversion was $9.6 \%$ and two-fold increased at 50 bar. The achieved $\mathrm{CO}$ conversions were far from the equilibrium (which decreased from $99.2 \%$ at 25 bar to $89.0 \%$ at 50 bar), which was a result of the slow kinetics due to the low reaction temperature.

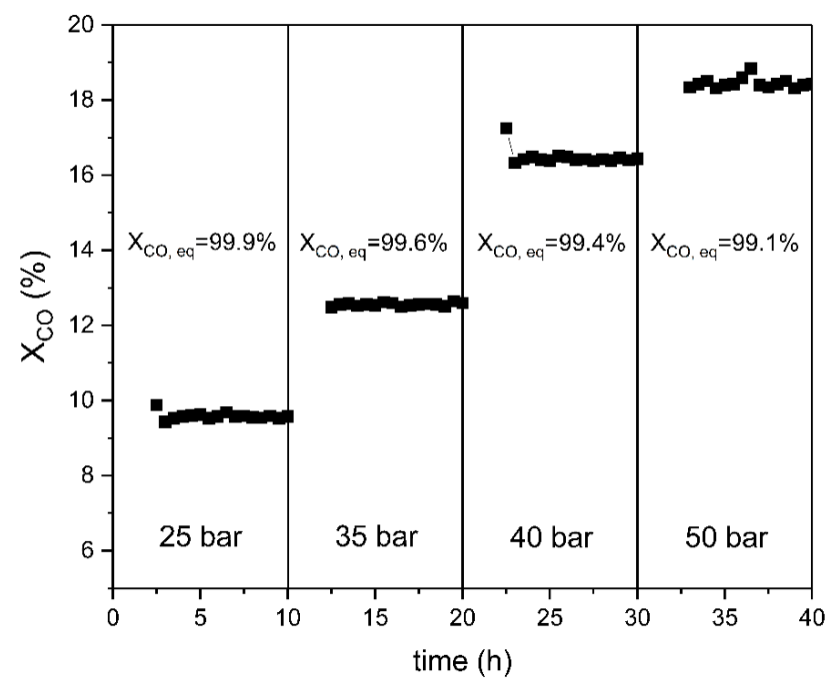

Figure 10. Conversion of $\mathrm{CO}$ in the presence of hydrogen over $0.3 \mathrm{Pt} / \mathrm{CoAl}$ catalyst at $220{ }^{\circ} \mathrm{C}$. Reaction conditions: $\mathrm{W}_{\text {cat }}=0.2 \mathrm{~g}, \mathrm{~F}_{\mathrm{H} 2 \mathrm{O}}=0.04 \mathrm{~mL} / \mathrm{min}, \mathrm{F}_{\mathrm{CO}}=3.5 \mathrm{~mL} / \mathrm{min}, \mathrm{F}_{\mathrm{H} 2}=14 \mathrm{~mL} / \mathrm{min}$.

Product yields $\left(\mathrm{Y}_{\mathrm{CO} 2}\right.$ and $\left.\mathrm{Y}_{\mathrm{CH} 4}\right)$ for $0.3 \mathrm{Pt} / \mathrm{CoAl}$ at different temperatures $(\mathrm{A})$ and pressure (B) values are displayed in Figure 11. $\mathrm{CO}_{2}$ yield turned out to be more sensitive to temperature than to pressure changes. For example, $\mathrm{CO}_{2}$ yield increased by $95 \%$ by passing from 220 to $235^{\circ} \mathrm{C}$. In like manner, a further increase in temperature to $260{ }^{\circ} \mathrm{C}$ caused an increase of about $140 \%$. On the contrary, methane yield hardly varied with temperature, though a slight tendency to decrease with increasing temperature could be deduced. This led to a substantial increase in $\mathrm{Y}_{\mathrm{CO} 2} / \mathrm{Y}_{\mathrm{CH}}$, with around a ten-fold increase in the 220 to $260^{\circ} \mathrm{C}$ range. As a result, the increase in WGS activity with respect to hydrogenation activity with increasing temperature is conclusive (Table 4). Regarding the influence of pressure on the product distribution, Figure 11B shows that $\mathrm{CO}_{2}$ yield slightly increased with pressure. Methane yield, however, increased ten-fold, from 25 to 50 bar. Therefore, the increased CO conversion at high pressure was due to a favored hydrogenation activity (i.e., ten-fold increase of $\mathrm{Y}_{\mathrm{CH} 4}$ in the 25 to 50 bar range) rather than the WGS. Note that, at a constant temperature, the vapor pressure of water remained constant, thus the increase in the operating pressure was accomplished by increasing the partial pressures of the $\mathrm{CO}$ and $\mathrm{H}_{2}$ (see Table $\mathrm{S} 2$ in Supplementary Materials). Although the water solubility of hydrogen is twice that of $\mathrm{CO}$, its effect on the available hydrogen in the gas 
phase was offset due to the high partial pressure of $\mathrm{H}_{2}$ under the established reaction conditions. Moreover, the fact that $\mathrm{CO}$ can react via WGS and produce even more hydrogen would also increase the hydrogenation rate [35]. The $\mathrm{Y}_{\mathrm{CO} 2} / \mathrm{Y}_{\mathrm{CH} 4}$ data in Table 4 clearly shows that the higher the overpressure, the less selectivity towards WGS, which is the opposite effect of the temperature increase.
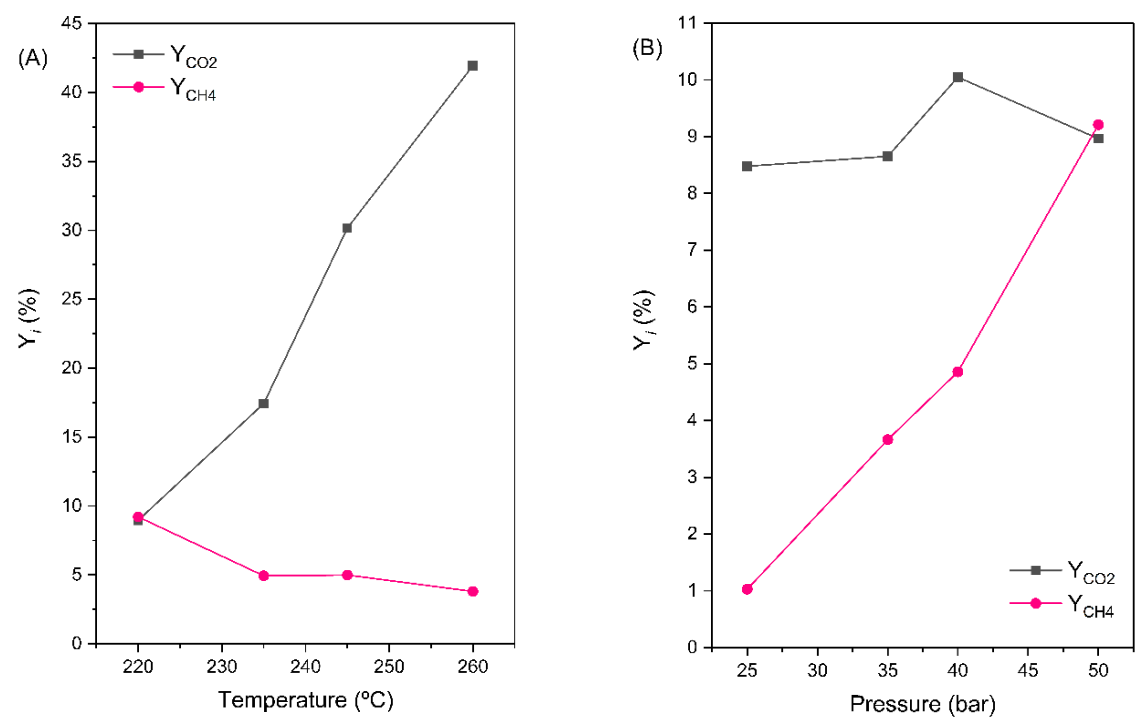

Figure 11. Evolution of product yields as a function of $(\mathbf{A})$ temperature at $\mathrm{P}=50$ bar and $(\mathbf{B})$ pressure at $\mathrm{T}=220{ }^{\circ} \mathrm{C}$ over $0.3 \mathrm{Pt} / \mathrm{CoAl}$. Reaction conditions: $\mathrm{W}_{\mathrm{cat}}=0.2 \mathrm{~g}, \mathrm{~F}_{\mathrm{H} 2 \mathrm{O}}=0.04 \mathrm{~mL} / \mathrm{min}, \mathrm{F}_{\mathrm{CO}}=3.5 \mathrm{~mL} / \mathrm{min}$, $\mathrm{F}_{\mathrm{H} 2}=14 \mathrm{~mL} / \mathrm{min}$.

The evolution of the net hydrogen variation is shown in Figure 12. A large net hydrogen consumption $\left(\Delta \mathrm{H}_{2}<0\right)$ was observed at low temperatures due to the high hydrogenation activity. It was verified that methane production decreased at increasing temperatures. Moreover, hydrogen consumption progressively decreased until a positive balance was obtained at the highest temperature screened. In agreement with the observed trend in the $\mathrm{CO}_{2}$ and $\mathrm{CH}_{4}$ yield, an increase in pressure favored selectivity towards $\mathrm{CO}$ hydrogenation. Hence, at the maximum working pressure, the rate of hydrogen consumption overtook that of production.

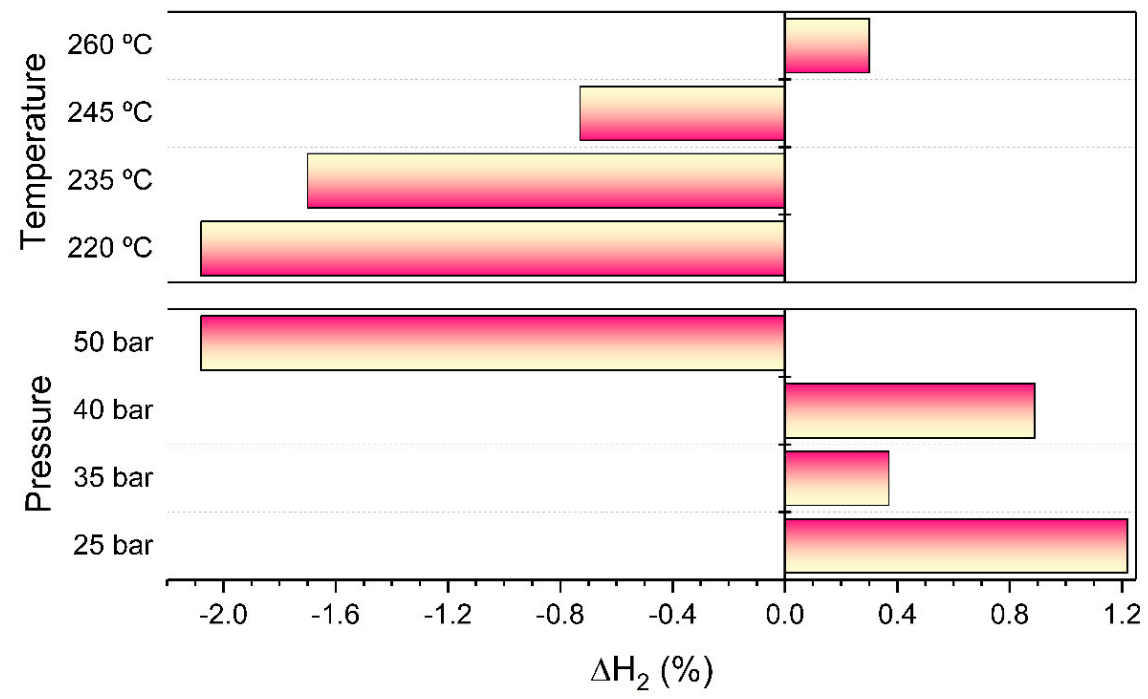

Figure 12. Net hydrogen variation in experiments with $\mathrm{H}_{2}$ co-feeding over $0.3 \mathrm{Pt} / \mathrm{CoAl}$ catalyst at 50 bar (upper part) and $220{ }^{\circ} \mathrm{C}$ (lower part). Reaction conditions: $\mathrm{W}_{\text {cat }}=0.2 \mathrm{~g}, \mathrm{~F}_{\mathrm{H} 2 \mathrm{O}}=0.04 \mathrm{~mL} / \mathrm{min}$, $\mathrm{F}_{\mathrm{CO}}=3.5 \mathrm{~mL} / \mathrm{min}, \mathrm{F}_{\mathrm{H} 2}=14 \mathrm{~mL} / \mathrm{min}$. 


\section{Materials and Methods}

\subsection{Catalyst Preparation}

Cobalt aluminate catalyst was synthesized using a protocol reported elsewhere [16]. Briefly, appropriate amounts of dissolved nitrate salts $\left(\mathrm{Co}\left(\mathrm{NO}_{3}\right)_{2} \cdot 6 \cdot \mathrm{H}_{2} \mathrm{O}\right.$ and $\left.\mathrm{Al}\left(\mathrm{NO}_{3}\right)_{3} \cdot 9 \cdot \mathrm{H}_{2} \mathrm{O}\right), \mathrm{Co} / \mathrm{Al}$ molar ratio of 0.625 , were coprecipitated into an aqueous solution of sodium carbonate at $\mathrm{pH} 10$. The resulting suspension was aged at room temperature for $24 \mathrm{~h}$, filtered, washed several times with de-ionized water, dried at $110^{\circ} \mathrm{C}$ for $17 \mathrm{~h}$ and calcined in a muffle furnace at $500{ }^{\circ} \mathrm{C}$ (heating rate $5^{\circ} \mathrm{C} / \mathrm{min}$ ) for $5 \mathrm{~h}$ in a static air atmosphere. This sample was abbreviated as CoAl.

Bimetallic $\mathrm{xPt} / \mathrm{CoAl}(\mathrm{x}: 0.3$ and $1 \mathrm{wt} . \%$ ) catalysts were prepared by the wet impregnation method. A controlled amount of aqueous solution of $\mathrm{Pt}\left(\mathrm{NH}_{3}\right)_{4}\left(\mathrm{NO}_{3}\right)_{2}$ (Alfa Aesar, \%99.99) was added to previously prepared CoAl. Then, the solids were dried at $110{ }^{\circ} \mathrm{C}$ for $17 \mathrm{~h}$ and finally calcined in air at $350{ }^{\circ} \mathrm{C}$ in a muffle furnace (heating rate $5{ }^{\circ} \mathrm{C} / \mathrm{min}$ ) for $3 \mathrm{~h}$. For comparative purposes, a $\gamma-\mathrm{Al}_{2} \mathrm{O}_{3}$-supported $\mathrm{Pt}$ catalyst was prepared by the same procedure (abbreviated $0.3 \mathrm{Pt} / \mathrm{Al}$ ). $\gamma$-alumina was prepared by calcination of $\mathrm{Al}\left(\mathrm{NO}_{3}\right)_{3} \cdot 9 \cdot \mathrm{H}_{2} \mathrm{O}$ in air, at $500{ }^{\circ} \mathrm{C}$ for $4 \mathrm{~h}$ (heating rate $5{ }^{\circ} \mathrm{C} / \mathrm{min}$ ).

\subsection{Catalyst Characterization}

Metal contents were determined by inductively coupled plasma-atomic emission spectroscopy (ICP-AES) with a Perkin Elmer Optima 8300 apparatus. The specific surface area $\left(\mathrm{S}_{\mathrm{BET}}\right)$, pore size distribution $\left(\mathrm{d}_{\text {pore }}\right)$ and pore volume $\left(\mathrm{V}_{\text {pore }}\right)$ were measured by nitrogen adsorption-desorption isotherms at $77 \mathrm{~K}$, carried out with the Micromeritics TriStar II 3020 apparatus. The samples were outgassed at $300^{\circ} \mathrm{C}$ for $10 \mathrm{~h}$ before the measurement. X-ray diffraction (XRD) studies were conducted on a PANalytical X'pert PRO diffractometer, using CuK $\alpha$ radiation $\left(\lambda_{\text {average }}=1.5418 \AA\right.$ ). Each sample was scanned from 10 to $90^{\circ}(2 \theta)$, with a step size of $0.026^{\circ}(2 \theta)$ and a counting time of $2 \mathrm{~s}$. Phase identification was done by comparison of the obtained spectra and the PDF database. The Scherrer equation, using a corrected full width at half maximum (FWHM) for instrumental broadening, was used to calculate the crystallite average size of the identified phases.

The reducibility of the samples was examined by temperature programmed reduction $\left(\mathrm{H}_{2}-\mathrm{TPR}\right)$ on a Micromeritics AutoChem 2920 apparatus equipped with a thermal conductivity detector (TCD). Before analysis, the sample (about $50 \mathrm{mg}$ ) was pretreated in He stream at $500{ }^{\circ} \mathrm{C}$ for $1 \mathrm{~h}$ (heating rate $10{ }^{\circ} \mathrm{C} / \mathrm{min}$ ) to clean the sample. Then, the temperature was cooled to ambient temperature into Ar flow. Finally, in $5 \% \mathrm{H}_{2}$-Ar flow, the temperature was ramped to $950{ }^{\circ} \mathrm{C}$ at $10^{\circ} \mathrm{C} / \mathrm{min}$ heating rate and held for $1 \mathrm{~h}$.

$\mathrm{H}_{2}$ chemisorption measurements were carried out on the same experimental setup used for $\mathrm{H}_{2}$-TPR experiments. Discrimination between $\mathrm{Pt}$ and $\mathrm{Co}$ metallic sites was effected by applying two consecutive pulse chemisorption analyses. Prior to the analysis, the surface was cleaned in He flow at $500{ }^{\circ} \mathrm{C}$. Then, catalysts were reduced at $250{ }^{\circ} \mathrm{C}$ in $5 \% \mathrm{H}_{2} / \mathrm{Ar}$ flow (heating rate $10^{\circ} \mathrm{C} / \mathrm{min}$, hold $1 \mathrm{~h}$ ) and cooled to $40^{\circ} \mathrm{C}$ in Ar flow. Pulses of $5 \% \mathrm{H}_{2} /$ Ar were injected (loop volume $0.5312 \mathrm{~mL}$ ) until peaks had equal areas. Secondly, the sample was heated in $5 \% \mathrm{H}_{2} /$ Ar flow to $600{ }^{\circ} \mathrm{C}$ (heating rate $10{ }^{\circ} \mathrm{C} / \mathrm{min}$, hold $1 \mathrm{~h}$ ) and evacuated in Ar for $15 \mathrm{~min}$. The temperature was cooled to $40{ }^{\circ} \mathrm{C}$ into Ar flow and a new $\mathrm{H}_{2}$ pulse chemisorption was completed. Hydrogen uptake by the sample reduced at $250{ }^{\circ} \mathrm{C}$ was assigned to Pt sites, while uptake after reduction at $600^{\circ} \mathrm{C}$ was assigned to both $\mathrm{Pt}$ and Co sites. $\mathrm{H} / \mathrm{Me}$ $(\mathrm{Me}=\mathrm{Pt}, \mathrm{Co})$ stoichiometry of $1 / 1$ was assumed. A spherical shape for Pt particles was assumed for the dispersion calculation, with $0.0655 \mathrm{~nm}^{2} /$ at.Pt.

High-angle annular dark field scanning transmission (HAADF-STEM) images were obtained on a Titan cube (FEI, Thermo Fisher, Hillboro, OR, USA) system operated at $300 \mathrm{kV}$ and coupled with a CCD camera (Gatan, Pleasanton, CA, USA). The nature of the particles was further confirmed by X-ray energy dispersive spectroscopy (X-EDS) in STEM mode. The samples for analysis were prepared by suspension of the corresponding sample in deionized water, dropping the suspension onto a 200-mesh carbon-coated copper grid and letting it dry under ambient air with the aid of anti-capillary tweezers. 
As the Pt particles were of the same shape, their average diameter was obtained from the measurement of at least 300 particles using ImageJ software, using the surface average diameter:

$$
<\mathrm{d}>=\Sigma \mathrm{n}_{\mathrm{i}} \mathrm{d}_{\mathrm{i}}^{3} / \Sigma \mathrm{n}_{\mathrm{i}} \mathrm{d}_{\mathrm{i}}^{2}\left(\mathrm{~d}_{\mathrm{i}}=\text { diameter of } \mathrm{n}_{\mathrm{i}} \text { particles }\right)
$$

For the calculation of the Pt dispersion from STEM, a spherical shape was assumed, with 1.3.1019 platinum atoms per unit area.

Total surface basicity was measured by weighing the sample upon $\mathrm{CO}_{2}$ chemisorption by thermogravimetry (Setaram Setsys, Caluire, France). About $80 \mathrm{mg}$ of sample was placed in an alumina crucible and in-situ reduced at $600{ }^{\circ} \mathrm{C}$ for $2 \mathrm{~h}$ under $50 \mathrm{~mL} / \mathrm{min} 5 \% \mathrm{H}_{2} / \mathrm{Ar}$ flow. The sample was then cooled to $50{ }^{\circ} \mathrm{C}$ under $50 \mathrm{~mL} / \mathrm{min} 5 \% \mathrm{H}_{2} / \mathrm{Ar}$ flow. Thereafter, the flow was switched to $5 \% \mathrm{CO}_{2} / \mathrm{He}$ $(16 \mathrm{~mL} / \mathrm{min})$ for $1 \mathrm{~h}$. Finally, the $\mathrm{CO}_{2}$ flow was stopped while $5 \% \mathrm{H}_{2} / \mathrm{Ar}(50 \mathrm{~mL} / \mathrm{min})$ was still circulated through the reactor for $1 \mathrm{~h}$ in order to desorb the physisorbed $\mathrm{CO}_{2}$. The eventual mass gain of the sample corresponded to the chemisorbed $\mathrm{CO}_{2}$.

X-ray photoelectron spectroscopy (XPS) was used to detect the electronic state of $\mathrm{Pt}, \mathrm{Co}$ and $\mathrm{Al}$ in the prepared samples. The spectra were measured using a SPECS spectrometer with Phoibos 150 1DDLD analyzer and monochromatized $\mathrm{Al} \mathrm{K} \alpha(1486.7 \mathrm{eV}) \mathrm{X}$-ray radiation in an ultrahigh vacuum. Binding energies were calibrated by taking the $\mathrm{C} 1$ s peak $(284.6 \mathrm{eV})$ of adventitious carbon as a reference. The peaks were deconvoluted after Shirley background subtraction, using a mixed Gaussian-Lorentzian function and concentrations were calculated by correcting the values with relative atomic sensitivity factors (Scofield).

Nitrogen isotherms and XRD were carried out for samples reduced ex-situ in a tubular quartz reactor at $600{ }^{\circ} \mathrm{C}$ for $1 \mathrm{~h}$ (heating rate $5{ }^{\circ} \mathrm{C} / \mathrm{min}$ ) in $50 \% \mathrm{H}_{2} / \mathrm{He}$ flow $(50 \mathrm{~mL} / \mathrm{min})$.

\subsection{Catalytic Activity}

Liquid-phase WGS reaction was carried out in a Hastelloy fixed-bed up-flow reactor $\left(D_{i}=5.1 \mathrm{~mm}\right.$; $\mathrm{L}=305 \mathrm{~mm}$ ) (Microactivity Effi, PID Eng\&Tech). A total of $0.2 \mathrm{~g}$ of catalyst was used in each experiment and was placed between two quartz wool plugs in the middle of the reactor. A K-type thermocouple, inserted from the reactor top, measured the temperature of the catalytic bed. Prior to the reaction, the catalyst was reduced under $10 \% \mathrm{H}_{2} / \mathrm{He}$ flow at $600{ }^{\circ} \mathrm{C}\left(0.3 \mathrm{Pt} / \mathrm{Al}\right.$ at $\left.300{ }^{\circ} \mathrm{C}\right)$ for $2 \mathrm{~h}$ (heating rate $5{ }^{\circ} \mathrm{C} / \mathrm{min}$ ) at atmospheric pressure. After pressurizing, the reactor temperature was increased at a rate of $5{ }^{\circ} \mathrm{C} / \mathrm{min}$. He was switched to bypass when the set temperature was attained. The liquid stream was pumped using an HPLC pump (Gilson 307) and the gas inlet was regulated by a mass flow controller (Bronkhorst High-Tech, Ruurlo, The Netherlands). The reactor outlet stream was separated into liquid and gas products by cooling with a Peltier cell at near atmospheric pressure; otherwise, the analysis of the gas production would be affected by the gaseous compounds dissolved in the water solution. The output gas flow was passed through a $100 \mathrm{~mL}$ mixing vessel in order to minimize the pulses of gas products coming from the reactor, and it was analyzed online every $15 \mathrm{~min}$ by a gas chromatograph ( $\mu$ GC Agilent) equipped with four parallel columns.

For the liquid-phase WGS reaction, $0.04 \mathrm{~mL} / \mathrm{min}$ of deionized water was fed together with $3.5 \mathrm{~mL} / \mathrm{min}(\mathrm{STP})$ of pure CO $\left(\mathrm{WHSV}=12.0 \mathrm{~h}^{-1}, \mathrm{GHSV}=1,050 \mathrm{~h}^{-1}\right.$, space-time $\left.=76.8 \mathrm{~kg}_{\mathrm{cat}} \cdot \mathrm{s} / \mathrm{mol}_{\mathrm{CO}}\right)$, giving $\mathrm{H}_{2} \mathrm{O} / \mathrm{CO}$ mole ratio $=15 / 1$. The catalytic tests were carried out at $260^{\circ} \mathrm{C}$ and 50 bar. Additional experiments co-feeding $\mathrm{H}_{2}$ were performed in the same reaction set-up and $\mathrm{H}_{2} \mathrm{O} / \mathrm{CO}$ feed flowrate. Pure $\mathrm{H}_{2}$ was provided to obtain different $\mathrm{H}_{2} / \mathrm{CO}$ ratios (4/3, 7/3 and 12/3). Furthermore, additional experiments were conducted with $0.3 \mathrm{Pt} / \mathrm{CoAl}$ catalysts in order to analyze the effects of reaction temperature and reaction pressure. In the first set of experiments, four levels of temperature were studied $\left(220,235,245\right.$ and $\left.260^{\circ} \mathrm{C}\right)$, operating at $\mathrm{H}_{2} / \mathrm{CO}$ ratio $=12 / 3$ and a steady pressure of 50 bar. In the second set of experiments, four levels of pressure were studied $(25,35,40$ and 50 bar) at isothermal conditions $\left(220^{\circ} \mathrm{C}\right)$ and $\mathrm{H}_{2} / \mathrm{CO}$ ratio $=12 / 3$. The carbon balance was over $98 \%$ for all the experiments. 
$\mathrm{CO}$ conversion $\left(\mathrm{X}_{\mathrm{CO}}\right), \mathrm{CO}_{2}$ and $\mathrm{CH}_{4}$ yields $\left(\mathrm{Y}_{\mathrm{i}}\right.$, where $\mathrm{i}: \mathrm{CO}_{2}$ or $\left.\mathrm{CH}_{4}\right)$ and net hydrogen variation $\left(\Delta \mathrm{H}_{2}\right)$ were calculated by using the corresponding inlet $\left(\mathrm{F}^{\mathrm{in}}\right)$ and outlet $\left(\mathrm{F}^{\text {out }}\right)$ molar flow values:

$$
\begin{gathered}
\mathrm{X}_{\mathrm{CO}}(\%)=100 \times \frac{\mathrm{F}_{\mathrm{CO}}^{\text {in }}-\mathrm{F}_{\mathrm{CO}}^{\text {out }}}{\mathrm{F}_{\mathrm{CO}}^{\text {in }}} \\
\mathrm{Y}_{\mathrm{i}}(\%)=100 \times \frac{\mathrm{F}_{\text {in }}^{\text {out }}}{\mathrm{F}_{\mathrm{CO}}^{\text {in }}} \\
\Delta \mathrm{H}_{2}(\%)=100 \times \frac{\mathrm{F}_{\mathrm{H}_{2}}^{\text {out }}-\mathrm{F}_{\mathrm{H}_{2}}^{\text {in }}}{\mathrm{F}_{\mathrm{H}_{2}}^{\text {in }}}
\end{gathered}
$$

In all the experiments, traces of $\mathrm{C}_{2+}$ alkanes were detected (with yield below $0.1 \%$ ). The sum of $\mathrm{CO}_{2}$ and $\mathrm{CH}_{4}$ yields matched the $\mathrm{CO}$ conversion, within the experimental error.

The different hydrodynamics of the APR reaction (where only liquid is fed and gas is formed) and the WGS carried out in this work (where both gas and liquid are co-fed) should be noted. In G-L-S catalytic systems, the liquid film around the catalyst particles can cause mass transfer limitations [42]. An important parameter in these kinds of systems is the liquid holdup $\left(\varepsilon_{\mathrm{L}}\right)$, which can cause the gas to bypass the catalyst for large $\varepsilon_{\mathrm{L}}$ values. The estimated $\varepsilon_{\mathrm{L}}$ values were below $20 \%$ for all the cases (Table S2, in Supplementary Materials).

\subsection{Gas-Liquid Equilibrium Calculation}

In order to gain knowledge on their solubility in water, Henry's law constants $(\mathrm{H})$ for the $\mathrm{CO}$, $\mathrm{CO}_{2}, \mathrm{H}_{2}$ and $\mathrm{CH}_{4}$ gases were estimated, from the experimental data in reference [43]. The units of the constants were bar/mole fraction in gas. The temperature dependence of the constants has been described by the Van't Hoff equation, which in its integrated form is the following:

$$
\mathrm{H}(\mathrm{T})=\mathrm{H}^{\mathrm{ref}} \cdot \exp ^{\left[-\frac{\Delta_{\mathrm{sol}} \mathrm{H}}{\mathrm{R}}\left(\frac{1}{\mathrm{~T}}-\frac{1}{\mathrm{~T}^{\mathrm{ref}}}\right)\right]}
$$

\begin{tabular}{|c|c|c|c|c|c|}
\hline \multirow{2}{*}{ Compound } & \multirow{2}{*}{$\Delta_{\text {sol }} \mathrm{H}(\mathrm{kJ} / \mathrm{mol})$} & \multicolumn{4}{|c|}{ H (bar/mole Fraction) $\left(\cdot 10^{-4}\right)$} \\
\hline & & (a) $220^{\circ} \mathrm{C}$ & @ $235^{\circ} \mathrm{C}$ & @ $245^{\circ} \mathrm{C}$ & @ $260^{\circ} \mathrm{C}$ \\
\hline $\mathrm{CO}$ & 10.8 & 32.0 & 34.6 & 36.4 & 39.0 \\
\hline $\mathrm{CO}_{2}$ & 19.9 & 4.0 & 4.7 & 5.1 & 5.8 \\
\hline $\mathrm{H}_{2}$ & 4.4 & 14.3 & 14.8 & 15.1 & 15.5 \\
\hline $\mathrm{CH}_{4}$ & 15.8 & 49.2 & 55.1 & 59.2 & 65.6 \\
\hline Vapor pressure of water (bar) & & 23.20 & 30.78 & 36.77 & 47.36 \\
\hline
\end{tabular}

$\mathrm{H}^{\mathrm{ref}}$ is the Henry's constant at a reference temperature $\mathrm{T}^{\mathrm{ref}}=298.15 \mathrm{~K}$, and $\Delta_{\text {sol }} \mathrm{H}$ is the enthalpy of dissolution. Table 6 shows the estimated $H$ values.

Table 6. Estimated $\mathrm{H}$ values and vapor pressure of water.

The total pressure in the gas phase was due to the partial pressures of the gas compounds and to the partial pressure of the water vaporized in equilibrium with the liquid phase. Assuming liquid-vapor equilibrium for the water phase, the vapor pressure of water was calculated by the Antoine equation, and the obtained values are given in Table 6.

As seen in Table 6, the solubility of the gases in water decreased with temperature. Among them, $\mathrm{CO}_{2}$ and $\mathrm{CH}_{4}$ were the most and least soluble, the latter being the most sensitive to temperature. Interestingly, the solubility of $\mathrm{H}_{2}$ is almost twice of that of $\mathrm{CO}$, which would decrease the $\mathrm{H}_{2} / \mathrm{CO}$ mole ratio in the gas phase. Indeed, the partial pressures of $\mathrm{CO}$ and $\mathrm{H}_{2}$ decreased with the increase of temperature, due to the increase in the partial pressure of water vapor. 


\section{Conclusions}

The catalytic performance of the liquid-phase water-gas Shift (WGS) reaction and CO hydrogenation was investigated over bimetallic Pt-Co catalysts and their monometallic counterparts. Bimetallic $x \mathrm{Pt} / \mathrm{CoAl}$ catalysts clearly outperformed monometallic ones in all the investigated operating conditions ( 220 to $260{ }^{\circ} \mathrm{C}, 25$ to 50 bar). The improved activity of these catalysts can be explained by their high density of basic sites, smaller particle size and the nature of the support. The strong Pt-Co interaction promoted reducibility and increased the availability of both metallic species.

It was concluded that bimetallic catalysts were more selective towards the WGS reaction than $\mathrm{CO}$ hydrogenation, despite the high availability of hydrogen in the reaction mixture. Furthermore, catalytic runs over $0.3 \mathrm{Pt} / \mathrm{CoAl}$ with excess hydrogen in the feedstream demonstrated the positive effect of increasing temperature on WGS activity. The opposite effect was reported with increasing pressure, which led to improved methane production.

Apparent reaction rates and activation energies were also reported in this study. Further research should focus on a detailed numerical analysis in order to gain further insight into the rate-determining step and the reaction mechanism and elucidate whether gas or liquid phase water molecules are involved in the reaction mechanism. The characterization of spent catalysts is another issue that should be well investigated to shed light on metal state and possible carbon species formation on the sample surface.

Supplementary Materials: The following are available online at http://www.mdpi.com/2073-4344/10/8/830/s1. Figure S1: Nitrogen isotherms (A) and pore size distribution (B) of the calcined (solid lines) and reduced (dashed lines) samples, Figure S2: EDX spectra of reduced samples: (A) CoAl, (B) $0.3 \mathrm{Pt} / \mathrm{CoAl}$, (C) $1 \mathrm{PtCoAl}$ and (D) 0.3Pt/Al, Figure S3: XPS spectra corresponding to $\mathrm{Pt}_{4} 4 \mathrm{~d}_{5 / 2}$, Figure S4: Outlet molar concentration of products during WGS reaction in the absence of hydrogen $\left(\mathrm{H}_{2} / \mathrm{CO}=0\right)$. Reaction conditions: $260^{\circ} \mathrm{C} / 50 \mathrm{bar} ; \mathrm{W}_{\text {cat }}(0.2 \mathrm{~g})$, water $(0.04 \mathrm{~mL} / \mathrm{min}), \mathrm{CO}(3.5 \mathrm{~mL} / \mathrm{min}, \mathrm{STP})$, Figure S5: Outlet molar concentration of products during WGS experiments at different $\mathrm{H}_{2} / \mathrm{CO}$ ratios. Reaction conditions: $260^{\circ} \mathrm{C} / 50$ bar; $\mathrm{W}_{\text {cat }}(0.2 \mathrm{~g})$, water $(0.04 \mathrm{~mL} / \mathrm{min})$, $\mathrm{CO}(3.5 \mathrm{~mL} / \mathrm{min}, \mathrm{STP}) ; \mathrm{H}_{2} / \mathrm{CO}=4 / 3(0-10 \mathrm{~h}), \mathrm{H}_{2} / \mathrm{CO}=7 / 3(11-20 \mathrm{~h})$ and $\mathrm{H}_{2} / \mathrm{CO}=4(21-30 \mathrm{~h})$, Figure S6: Outlet molar concentration of products during WGS experiments at different temperatures and pressures over $\mathrm{Pt} / \mathrm{CoAl}$. Reaction conditions: $\mathrm{W}_{\text {cat }}(0.2 \mathrm{~g})$, water $(0.04 \mathrm{~mL} / \mathrm{min}), \mathrm{CO}(3.5 \mathrm{~mL} / \mathrm{min}, \mathrm{STP}), \mathrm{H}_{2}(14 \mathrm{~mL} / \mathrm{min}, \mathrm{STP})$. Upper part: temperature variation $\left(220,235,245,260^{\circ} \mathrm{C}\right)$ and 50 bar. Lower part: pressure variation $(25,35,40$, $50 \mathrm{bar}$ ) and $220^{\circ} \mathrm{C}$. Table S1. List of apparent activation energies reported in this work and in the literature for Pt catalysts. Table S2. Liquid holdup $\left(\varepsilon_{\mathrm{L}}\right)$, vapor composition and liquid/vapor distribution of $\mathrm{CO}$ and $\mathrm{H}_{2}$.

Author Contributions: Investigation and writing-original draft preparation, A.J.R.; conceptualization, methodology and writing — review and editing, J.L.A.; formal analysis and writing—review and editing, U.I.-V.; resources, funding acquisition and supervision, M.Á.G.-O. All authors have read and agreed to the published version of the manuscript.

Funding: This research was funded by Mineco (ENE2016-74850-R and PID2019-106692EB-I00) and FEDER. The APC was funded by ENE2016-74850-R. A.J.R. was supported by a PhD research fellowship provided by the University of the Basque Country UPV/EHU (PIF-17/319).

Acknowledgments: The authors are grateful for the technical support provided by SGIker of UPV/EHU and European funding (ERDF and ESF). The TEM measurements were conducted at the Laboratorio de Microscopías Avanzadas, Instituto de Nanociencia de Aragon, University of Zaragoza, Spain.

Conflicts of Interest: The authors declare no conflict of interest. The funders had no role in the design of the study; in the collection, analyses, or interpretation of data; in the writing of the manuscript, or in the decision to publish the results.

\section{References}

1. Burns, D.T.; Piccardi, G.; Sabbatini, L. Some people and places important in the history of analytical chemistry in Italy. Microchim. Acta 2007, 160, 57-87. [CrossRef]

2. Meland, H.; Johannessen, T.; Arstad, B.; Venvik, H.J.; Rønning, M.; Holmén, A. Preparation of low temperature water-gas shift catalysts by flame spray pyrolysis. Stud. Surf. Sci. Catal. 2006, 162, 985-992. [CrossRef]

3. Damma, D.; Boningari, T.; Smirniotis, P. High-temperature water-gas shift over Fe/Ce/Co spinel catalysts: Study of the promotional effect of Ce and Co. Mol. Catal. 2018, 451, 20-32. [CrossRef] 
4. Noor, T.; Gil, M.V.; Chen, D. Production of fuel-cell grade hydrogen by sorption enhanced water gas shift reaction using Pd/Ni-Co catalysts. Appl. Catal. B Environ. 2014, 150, 585-595. [CrossRef]

5. Pardey, A.J.; Ford, P.C. Homogeneous catalysis of the water-gas shift reaction by rhodium complexes in aqueous substituted pyridine solutions. J. Mol. Catal. 1989, 53, 247-263. [CrossRef]

6. Laine, R.M.; Crawford, E.J. Homogeneous catalysis of the water-gas shift reaction. J. Mol. Catal. 1988, 44, 357-387. [CrossRef]

7. Wolf, P.; Aubermann, M.; Wolf, M.; Bauer, T.; Blaumeiser, D.; Stepic, R.; Wick, C.R.; Smith, D.M.; Smith, A.-S.; Wasserscheid, P.; et al. Improving the performance of supported ionic liquid phase (SILP) catalysts for the ultra-low-temperature water-gas shift reaction using metal salt additives. Green Chem. 2019, 21, 5008-5018. [CrossRef]

8. Kim, M.-S.; Fitriana, H.N.; Kim, T.W.; Kang, S.G.; Jeon, S.G.; Chung, S.H.; Park, G.W.; Na, J.-G. Enhancement of the hydrogen productivity in microbial water gas shift reaction by Thermococcus onnurineus NA1 using a pressurized bioreactor. Int. J. Hydrogen Energy 2017, 42, 27593-27599. [CrossRef]

9. Cortright, R.D.; Davda, R.R.; Dumesic, J.A. Hydrogen from catalytic reforming of biomass-derived hydrocarbons in liquid water. Nature 2002, 418, 964-967. [CrossRef]

10. Davda, R.; Shabaker, J.; Huber, G.; Cortright, R.; Dumesic, J.A. Aqueous-phase reforming of ethylene glycol on silica-supported metal catalysts. Appl. Catal. B Environ. 2003, 43, 13-26. [CrossRef]

11. D'Angelo, M.F.N.; Schouten, J.C.; Van Der Schaaf, J.; Nijhuis, T. Three-Phase Reactor Model for the Aqueous Phase Reforming of Ethylene Glycol. Ind. Eng. Chem. Res. 2014, 53, 13892-13902. [CrossRef]

12. Guo, Y.; Azmat, M.U.; Liu, X.; Wang, Y.; Lu, G. Effect of support's basic properties on hydrogen production in aqueous-phase reforming of glycerol and correlation between WGS and APR. Appl. Energy 2012, 92, 218-223. [CrossRef]

13. Ciftci, A.; Ligthart, D.M.; Sen, A.O.; Van Hoof, A.; Friedrich, H.; Hensen, E.J. Pt-Re synergy in aqueous-phase reforming of glycerol and the water-gas shift reaction. J. Catal. 2014, 311, 88-101. [CrossRef]

14. Ripken, R.M.; Meuldijk, J.; Gardeniers, H.J.; Le Gac, S. Influence of the Water Phase State on the Thermodynamics of Aqueous-Phase Reforming for Hydrogen Production. ChemSusChem 2017, 10, 4909-4913. [CrossRef] [PubMed]

15. Godina, L.I.; Kirilin, A.V.; Tokarev, A.V.; Simakova, I.L.; Murzin, D.Y. Sibunit-Supported Mono- and Bimetallic Catalysts Used in Aqueous-Phase Reforming of Xylitol. Ind. Eng. Chem. Res. 2018, 57, 2050-2067. [CrossRef]

16. Reynoso, A.; Ayastuy, J.; Iriarte-Velasco, U.; Gutiérrez-Ortiz, M. Chemical Technologies for the Environmental Sustainability Group Cobalt aluminate spinel-derived catalysts for glycerol aqueous phase reforming. Appl. Catal. B Environ. 2018, 239, 86-101. [CrossRef]

17. Kirilin, A.V.; Tokarev, A.V.; Manyar, H.; Hardacre, C.; Salmi, T.; Mikkola, J.-P.; Murzin, D.Y. Aqueous phase reforming of xylitol over Pt-Re bimetallic catalyst: Effect of the Re addition. Catal. Today 2014, 223, 97-107. [CrossRef]

18. Subramanian, N.D.; Callison, J.; Catlow, C.R.A.; Wells, P.P.; Dimitratos, N. Optimised hydrogen production by aqueous phase reforming of glycerol on $\mathrm{Pt}_{\mathrm{t}} \mathrm{Al}_{2} \mathrm{O}_{3}$. J. Hydrogen Energy 2016, 41, 18441-18450. [CrossRef]

19. De León, J.D.; Loera-Serna, S.; Zepeda, T.; Domínguez, D.; Pawelec, B.; Venezia, A.; Fuentes-Moyado, S. Noble metals supported on binary $\gamma-\mathrm{Al}_{2} \mathrm{O}_{3}-\alpha-\mathrm{Ga}_{2} \mathrm{O}_{3}$ oxide as potential low-temperature water-gas shift catalysts. Fuel 2020, 266. [CrossRef]

20. Zhang, S.; Shan, J.; Zhu, Y.; Frenkel, A.I.; Patlolla, A.; Huang, W.; Yoon, S.J.; Wang, L.; Yoshida, H.; Takeda, S.; et al. WGS Catalysis and In Situ Studies of $\mathrm{CoO}_{1-\mathrm{x}}, \mathrm{PtCo}_{\mathrm{n}} / \mathrm{Co}_{3} \mathrm{O}_{4}$, and $\mathrm{Pt}_{\mathrm{m}} \mathrm{Co}_{\mathrm{m}^{\prime}} / \mathrm{CoO}_{1-\mathrm{x}}$ Nanorod Catalysts. J. Am. Chem. Soc. 2013, 135, 8283-8293. [CrossRef]

21. Dietrich, P.J.; Akatay, M.C.; Sollberger, F.G.; Stach, E.A.; Miller, J.T.; Delgass, W.N.; Ribeiro, F.H. Effect of Co Loading on the Activity and Selectivity of PtCo Aqueous Phase Reforming Catalysts. ACS Catal. 2014, 4, 480-491. [CrossRef]

22. Dosso, L.A.; Vera, C.R.; Grau, J.M.; Grau, J.M. Aqueous phase reforming of polyols from glucose degradation by reaction over Pt/alumina catalysts modified by Ni or Co. Int. J. Hydrogen Energy 2017, 42, 18853-18864. [CrossRef]

23. Le, T.A.; Kim, M.S.; Lee, S.H.; Park, E.D. $\mathrm{CO}$ and $\mathrm{CO}_{2}$ Methanation Over Supported Cobalt Catalysts. Top. Catal. 2017, 60, 714-720. [CrossRef]

24. Reynoso, A.; Iriarte-Velasco, U.; Gutiérrez-Ortiz, M.A.; Ayastuy, J. Highly stable $\mathrm{Pt} / \mathrm{CoAl}_{2} \mathrm{O}_{4}$ catalysts in Aqueous-Phase Reforming of glycerol. Catal. Today 2020. [CrossRef] 
25. Benvenutti, E.V.; Franken, L.; Moro, C.; DaVanzo, C.U. FTIR Study of Hydrogen and Carbon Monoxide Adsorption on $\mathrm{Pt} / \mathrm{TiO}_{2}, \mathrm{Pt} / \mathrm{ZrO}_{2}$, and $\mathrm{Pt} / \mathrm{Al}_{2} \mathrm{O}_{3}$. Langmuir 1999, 15, 8140-8146. [CrossRef]

26. Liu, Y.; Jia, L.; Hou, B.; Sun, D.; Li, D. Cobalt aluminate-modified alumina as a carrier for cobalt in Fischer-Tropsch synthesis. Appl. Catal. A Gen. 2017, 530, 30-36. [CrossRef]

27. Zhang, J.-M.; Sun, S.-N.; Li, Y.; Zhang, X.; Zhang, P.-Y.; Fan, Y.-J. A strategy in deep eutectic solvents for carbon nanotube-supported PtCo nanocatalysts with enhanced performance toward methanol electrooxidation. Int. J. Hydrogen Energy 2017, 42, 26744-26751. [CrossRef]

28. Khassin, A.; Yurieva, T.M.; Kaichev, V.; Bukhtiyarov, V.I.; Budneva, A.A.; Paukshtis, E.A.; Parmon, V.N. Metal-support interactions in cobalt-aluminum co-precipitated catalysts: XPS and CO adsorption studies. J. Mol. Catal. A Chem. 2001, 175, 189-204. [CrossRef]

29. Bergman, S.L.; Granestrand, J.; Tang, Y.; París, R.S.; Nilsson, M.; Tao, F.F.; Tang, C.; Pennycook, S.J.; Pettersson, L.J.; Bernasek, S.L. In-situ characterization by Near-Ambient Pressure XPS of the catalytically active phase of $\mathrm{Pt} / \mathrm{Al}_{2} \mathrm{O}_{3}$ during $\mathrm{NO}$ and $\mathrm{CO}$ oxidation. Appl. Catal. B Environ. 2018, 220, 506-511. [CrossRef]

30. Kannan, S.; Swamy, C. Catalytic decomposition of nitrous oxide over calcined cobalt aluminum hydrotalcites. Catal. Today 1999, 53, 725-737. [CrossRef]

31. Iriondo, A.; Cambra, J.F.; Barrio, V.; Güemez, M.; Arias, P.L.; Sanchez-Sanchez, M.; Navarro, R.; Fierro, J.L.G. Glycerol liquid phase conversion over monometallic and bimetallic catalysts: Effect of metal, support type and reaction temperatures. Appl. Catal. B Environ. 2011, 106, 83-93. [CrossRef]

32. De Farias, A.M.D.; Barandas, A.P.; Perez, R.F.; Fraga, M. Water-gas shift reaction over magnesia-modified $\mathrm{Pt} / \mathrm{CeO}_{2}$ catalysts. J. Power Sources 2007, 165, 854-860. [CrossRef]

33. Dietrich, P.J.; Sollberger, F.G.; Akatay, M.C.; Stach, E.A.; Delgass, W.N.; Miller, J.T.; Ribeiro, F.H. Structural and catalytic differences in the effect of $\mathrm{Co}$ and $\mathrm{Mo}$ as promoters for Pt-based aqueous phase reforming catalysts. Appl. Catal. B Environ. 2014, 156, 236-248. [CrossRef]

34. Miao, B.; Ma, S.S.K.; Wang, X.; Su, H.; Chan, S.H. Catalysis mechanisms of CO2 and CO methanation. Catal. Sci. Technol. 2016, 6, 4048-4058. [CrossRef]

35. Chen, W.; Pestman, R.; Zijlstra, B.; Filot, I.A.W.; Hensen, E.J. Mechanism of Cobalt-Catalyzed CO Hydrogenation: Methanation. ACS Catal. 2017, 7, 8050-8060. [CrossRef] [PubMed]

36. Liu, Q.; Bian, B.; Fan, J.; Yang, J. Cobalt doped Ni based ordered mesoporous catalysts for $\mathrm{CO}_{2}$ methanation with enhanced catalytic performance. Int. J. Hydrogen Energy 2018, 43, 4893-4901. [CrossRef]

37. Jahangiri, H.; Bennett, J.; Mahjoubi, P.; Wilson, K.; Gu, S. A review of advanced catalyst development for Fischer-Tropsch synthesis of hydrocarbons from biomass derived syn-gas. Catal. Sci. Technol. 2014, 4, 2210-2229. [CrossRef]

38. Herranz, T.; Deng, X.; Cabot, A.; Guo, J.; Salmeron, M. Influence of the Cobalt Particle Size in the CO Hydrogenation Reaction Studied by In Situ X-Ray Absorption Spectroscopy. J. Phys. Chem. B 2009, 113, 10721-10727. [CrossRef]

39. Xiang, Y.; Kovarik, L.; Kruse, N. Rate and selectivity hysteresis during the carbon monoxide hydrogenation over promoted Co/MnOx catalysts. Nat. Commun. 2019, 10, 3953-3957. [CrossRef]

40. Shabaker, J. Aqueous-phase reforming of methanol and ethylene glycol over alumina-supported platinum catalysts. J. Catal. 2003, 215, 344-352. [CrossRef]

41. Catti, M.; Ghaani, M.R.; Pinus, I. Overpressure Role in Isothermal Kinetics of H2 Desorption-Absorption: The $2 \mathrm{LiBH}_{4}-\mathrm{Mg}_{2} \mathrm{FeH}_{6}$ System. J. Phys. Chem. C 2013, 117, 26460-26465. [CrossRef]

42. Lévêque, J.; Philippe, R.; Zanota, M.-L.; Meille, V.; Sarrazin, F.; Baussaron, L.; De Bellefon, C. Hydrodynamics and mass transfer in a tubular reactor containing foam packings for intensification of G-L-S catalytic reactions in co-current up-flow configuration. Chem. Eng. Res. Des. 2016, 109, 686-697. [CrossRef]

43. Sander, R. Compilation of Henry's law constants (version 4.0) for water as solvent. Atmos. Chem. Phys. Discuss. 2015, 15, 4399-4981. [CrossRef]

(C) 2020 by the authors. Licensee MDPI, Basel, Switzerland. This article is an open access article distributed under the terms and conditions of the Creative Commons Attribution (CC BY) license (http://creativecommons.org/licenses/by/4.0/). 